NBER WORKING PAPER SERIES

\title{
HOW SOCIAL PROCESSES DISTORT MEASUREMENT: THE IMPACT OF SURVEY NONRESPONSE ON ESTIMATES OF VOLUNTEER WORK
}

\author{
Katharine G. Abraham \\ Sara E. Helms \\ Stanley Presser \\ Working Paper 14076 \\ http://www.nber.org/papers/w14076 \\ NATIONAL BUREAU OF ECONOMIC RESEARCH \\ 1050 Massachusetts Avenue \\ Cambridge, MA 02138 \\ June 2008
}

We are grateful to Robert Groves, Howard Schuman, Roger Tourangeau, and three anonymous referees, as well as participants in the June 2007 Institute for the Study of Labor (IZA) "Nonmarket Uses of Time" topic week and the 2007 meetings of the International Association for Time Use Research, for helpful comments on earlier drafts of this paper. Helms received support for her work on this project from the National Science Foundation through an ADVANCE grant to the University of Alabama at Birmingham (SBE-0245090). Direct correspondence to Katharine G. Abraham (kabraham @ survey.umd.edu) or Stanley Presser (spresser@ socy.umd.edu), Joint Program in Survey Methodology, University of Maryland, 1218 Lefrak Hall, College Park, MD 20742. The views expressed herein are those of the author(s) and do not necessarily reflect the views of the National Bureau of Economic Research.

NBER working papers are circulated for discussion and comment purposes. They have not been peerreviewed or been subject to the review by the NBER Board of Directors that accompanies official NBER publications.

(C) 2008 by Katharine G. Abraham, Sara E. Helms, and Stanley Presser. All rights reserved. Short sections of text, not to exceed two paragraphs, may be quoted without explicit permission provided that full credit, including $\odot$ notice, is given to the source. 
How Social Processes Distort Measurement: The Impact of Survey Nonresponse on Estimates of Volunteer Work in the United States

Katharine G. Abraham, Sara E. Helms, and Stanley Presser

NBER Working Paper No. 14076

June 2008

JEL No. J01

\begin{abstract}
Estimates of volunteering in the United States vary greatly from survey to survey and do not show the decline over time common to other measures of social capital. We argue that these anomalies are caused by the social processes that determine survey participation, in particular the propensity of people who do volunteer work to respond to surveys at higher rates than those who do not do volunteer work. Thus surveys with lower responses rates will usually have higher proportions of volunteers, and the decline in response rates over time likely has led to increasing overrepresentation of volunteers. We analyze data from the American Time Use Survey (ATUS) -- the sample for which is drawn from Current Population Survey (CPS) respondents -- together with data from the CPS Volunteering Supplement to demonstrate the effects of survey nonresponse on estimates of volunteering activity and its correlates. CPS respondents who become ATUS respondents report much more volunteering in the CPS than those who become ATUS nonrespondents. This difference is replicated within demographic and other subgroups. Consequently, conventional statistical adjustments for nonresponse cannot correct the resulting bias. Although nonresponse leads to estimates of volunteer activity that are too high, it generally does not affect inferences about the characteristics associated with volunteer activity. We discuss the implications of these findings for the study of other phenomena.
\end{abstract}

Katharine G. Abraham

Joint Program in Survey Methodology

1218 LeFrak Hall

University of Maryland

College Park, MD 20742

and NBER

kabraham@survey.umd.edu

Sara E. Helms

Department of Finance,

BEC 317-F

University of Alabama at Birmingham

1530 3rd Ave South

Birmingham, AL 35294

shelms@uab.edu

\author{
Stanley Presser \\ Department of Sociology and Joint Program \\ in Survey Methodology \\ 1218 LeFrak Hall \\ Joint Program in Survey Methodology \\ College Park, MD 20742 \\ spresser@socy.umd.edu
}


Volunteer work is an important component of economic activity in the United States (Abraham and Mackie 2005) and it also plays a key role in noneconomic spheres of American society (Wilson 2000). Who volunteers and why? What sorts of work do volunteers perform? Have the amount and type of volunteer work changed over time? How does volunteering affect volunteers? What cultural and political factors influence the amount and nature of volunteering in a society? How does volunteering shape culture and the polity? These are among the questions that make volunteering of interest across the social sciences.

Such questions are most often addressed with data from sample surveys. Troublingly, however, surveys yield widely varying estimates of volunteering. For instance, the 2002 Supplement to the Current Population Survey (CPS), conducted by the Census Bureau, reported that 28 percent of American adults were volunteers (Boraas, 2003); the 1996 National Household Education Survey (NHES), conducted by Westat, reported a figure of 39 percent (National Center for Education Statistics, 1997); and the 1996 Independent Sector (IS) survey, conducted by the Gallup Poll, estimated 49 percent (Hodgkinson and Weitzman, 1996).

These surveys differed in many ways (including the precise definition of volunteering), but one of the most pronounced differences was the proportion of sample members from whom information was collected. The response rate to the CPS supplement was 82 percent (Census Technical Documentation); the rate for NHES was 59 percent (National Center for Education Statistics, 1997); and, although we have been unable to obtain the rate for the IS survey, Gallup response rates rarely exceeded 40 percent. The variation in these rates corresponds to the variation in the volunteering estimates - the higher the response rate the lower the volunteering estimate.

Although this is, at best, suggestive evidence for the proposition that survey estimates of volunteering are inversely related to survey response rates, such a proposition makes sense of a 
second puzzling survey finding about volunteering: Change over time in volunteering appears quite different from change over time in other forms of social capital. In Bowling Alone, Putnam (2000: 127) noted that "Trends in volunteering over the last several decades are more complicated and in some respects more intriguing than the uniform decline that characterizes most dimensions of social capital in America in this period." As shown in Figure 1, nationwide Gallup surveys recorded a sharp increase between 1977 and 1991 in affirmative responses to the question "Do you, yourself, happen to be involved in any charity or social service activities, such as helping the poor, the sick or the elderly?" The percent of affirmative responses rose from 26 percent in 1977 to 46 percent in $1991 .{ }^{1}$

If these data are taken at face value, they indicate that volunteering in America almost doubled in little more than a decade! But over this same period, survey response rates declined markedly due to increasing difficulties in both contacting people and persuading them to be interviewed (see Curtin, Presser, and Singer 2005, for the experiences of one major survey). Response rates are not available for the Figure 1 surveys, but the Gallup Organization experienced a general decline during this period similar to that of most survey organizations. Further, the first five surveys shown in Figure 1 (from 1977 through 1986) were conducted faceto-face, whereas the other four (between 1987 and 1991) were conducted by telephone. Thus, even apart from the general decline in response rates, the later studies would have had lower response rates than the earlier ones because response rates are almost always lower on the phone than in-person (Groves and Kahn, 1979). Moreover, the December 1987 survey, which produced the highest estimate of volunteering, almost certainly had the lowest response rate, as it

\footnotetext{
${ }^{1}$ The question wording in two of the surveys contained very minor variations. The December 1987 poll substituted "Are you involved..." for "Do you, yourself, happen to be involved..." and the November 1989 poll deleted "yourself" from "Do you, yourself, happen to be involved..." Also, the final entry (1991) is from a survey by Princeton Survey Research Associates, which had been founded the previous year by individuals who had been responsible for Gallup's 1989 volunteering survey.
} 
was conducted over only two days compared to seven days for the May 1987 survey and four days for all the other surveys. (Shorter field periods produce lower response rates because they allow less time to contact and persuade respondents.) $)^{2}$

\section{FIGURE 1 ABOUT HERE}

Are there grounds for expecting that a survey's response rate would affect its estimate of volunteering? Although the potential for nonresponse bias grows as the level of nonresponse increases, several recent studies, on a wide range of topics, have found that actual nonresponse bias is largely unaffected by increases in the nonresponse rate. Keeter et al. (2000), Curtin, Presser, and Singer (2000), and Merkle and Edelman (2002) report little, if any, link between nonresponse rates and bias, and a meta-analysis by Groves (2006) shows only a weak relationship between nonresponse level and bias in studies that had validation measures. These results suggest that many of the variables measured in surveys are only slightly correlated, if at all, with the causes of nonresponse (cf., Groves, Presser, and Dipko, 2004 and Abraham, Maitland and Bianchi, 2006).

\footnotetext{
${ }^{2}$ The only volunteering time series we know of for which published response rates are available is the American National Election Study, which, beginning in 1992, asked the following question in five post-election surveys: "Many people say they have less time these days to do volunteer work. What about you, were you able to devote any time to volunteer work in the last 12 months?" The samples used for three of the five years were drawn in part from respondents to earlier surveys. Unfortunately, this is not reflected in the published response rates, and we are unable to compute the correct response rates for the total samples in those years. Instead, we present below the results from the newly drawn portions of the samples. The new samples for 1996 and 2002 were quite small; in addition, there were differences in the mode of administration across the surveys (2004 was conducted completely in-person, 2002 completely by phone, and the others with varying percentages allocated to the two modes), which complicates interpretation. Among the three surveys with samples large enough to produce reasonably precise estimates (1992, 2000 and 2004), we observe the lowest percent volunteering in the sample with the highest response rate (1992) and the highest percent volunteering in the sample with the lowest response rate (2000), though the 2000 estimate is not significantly different from the 2004 estimate.

\begin{tabular}{ccc} 
& Response Rate & \multicolumn{2}{c}{ \% Volunteered } \\
1992 & 66.3 & $36.6(\mathrm{n}=999)$ \\
1996 & 51.0 & $40.6(\mathrm{n}=335)$ \\
2000 & 52.1 & $42.8(\mathrm{n}=1555)$ \\
2002 & 30.0 & $42.4(\mathrm{n}=276)$ \\
2004 & 58.1 & $41.7(\mathrm{n}=1066)$
\end{tabular}
}


Volunteering is likely to be an exception to this pattern. The two major determinants of response rate -- contactability (the ease of being able to make contact with an individual) and amenability (an individual's willingness to be interviewed) - both seem likely to be influenced by the same factors that influence volunteering: social integration, altruism, and a sense of responsibility. Indeed survey participation is similar to volunteering in that survey respondents are asked to help an organization by giving their time (Knack, 1992). ${ }^{3}$ There is thus a theoretical basis for expecting volunteering, as well as other pro-social or altruistic behaviors, to be related to nonresponse and, therefore, to be overestimated in surveys.

Nonresponse bias is not the only form of error that may affect survey estimates of volunteering (or other pro-social behavior). The estimates are also subject to recall error and social desirability bias. These two problems are minimized in the American Time Use Survey (ATUS), which, beginning in 2003, obtained detailed reports from a sample of Americans about how they spent their time on the day preceding the interview (Bureau of Labor Statistics and U.S. Census Bureau, 2005). Recall error is curtailed because of the very short reference period, and social desirability bias is unlikely because respondents are simply asked to report, in chronological order, everything they did yesterday. Only after respondents report all their activities does the interviewer ask whether any of them involved volunteering. As the ATUS response rate has been only about 50 percent, however, the ATUS estimate of volunteering may be subject to considerable nonresponse bias.

In this paper, we assess the nonresponse error in the ATUS estimate of volunteering. This is possible because a random subsample of the ATUS was previously part of the Current

\footnotetext{
${ }^{3}$ In fact, Keeter et al.'s (2000: 140) methodological experiment found significantly more volunteering in a survey with a relatively low response rate than in a comparable survey with a much higher response rate. But in the context of the large number of comparisons made in that study (the great majority of which showed no difference), sampling error seemed a plausible explanation for the finding.
} 
Population Survey (CPS) Volunteering Supplement, which attained a much higher response rate than the ATUS (over 80 percent). We compare the CPS volunteering estimates for two groups of Supplement respondents: those who became ATUS respondents and those who became ATUS nonrespondents. We find a very large difference consistent with the hypothesis that ATUS respondents are more likely than ATUS nonrespondents to be volunteers. In the CPS, ATUS respondents reported volunteering at a rate 75 percent higher than did ATUS nonrespondents. Furthermore, the nonresponse bias is evident within demographic and other subgroups, which means that conventional statistical adjustments for nonresponse (e.g., weighting class adjustments and response propensity models) would not correct the bias.

Our demonstration of the impact of nonresponse on volunteering estimates, coupled with the finding that the bias is immune to conventional nonresponse adjustments, provides an important qualification to the recent literature on the effects of nonresponse and has profound implications for the study of volunteering, as well as, most likely, for the study of many other pro-social behaviors, such as making charitable contributions, donating blood or organs, and providing help to strangers in routine or emergency situations.

Although these analyses suggest that nonresponse plays a central role in inferences about the amount of volunteering in the United States (as well as about changes over time in the amount of volunteering), they are not informative about how nonresponse affects inferences about the causes and consequences of volunteering. To that end, we next investigate the impact of the nonresponse error on estimates of the correlates of volunteering activity. We do this by comparing models of volunteering in the CPS estimated for ATUS respondents with models estimated for ATUS respondents and nonrespondents combined. The results are very similar: Although nonresponse has a powerful effect on the univariate distribution of volunteering, it does not affect inferences about the respondent characteristics that are associated with 
volunteering. The possibility that multivariate analyses are more immune to nonresponse than univariate analysis has potentially far-reaching implications for surveys on a wide range of topics.

Finally, supplementing these analyses, which are based on volunteering estimates from the CPS, we examine the volunteering estimates from the ATUS itself. As expected, the ATUS univariate estimate of volunteer hours is much higher than the overall CPS estimate and closer to the CPS estimate using only cases that later became ATUS respondents. In addition, inferences from the ATUS sample about the relation between volunteer hours and other respondent characteristics are similar to those from the total CPS sample, again suggesting that nonresponse bias -- despite its impact on the level of volunteering -- does not pose a serious problem for inferences about the correlates of volunteering.

\section{DATA}

The data used in our analysis come from two sources: the September 2003 Current Population Survey Volunteering Supplement, and the 2003 and 2004 American Time Use Survey. The fact that the American Time Use Survey sample is drawn from persons in households that responded to the Current Population Survey makes our analysis possible.

\section{Current Population Survey (CPS) Volunteering Supplement}

The Current Population Survey (CPS) is a monthly household survey sponsored by the Bureau of Labor Statistics (BLS) and conducted by the U.S. Census Bureau. The survey uses an area probability sample of the 50 states and the District of Columbia yielding almost 60,000 households per month. In order to facilitate state-level estimates, smaller states are oversampled. CPS households are contacted for interviews in four consecutive months (Months in Sample, or MIS, 1-4); leave the sample for the next eight months; and then return for four additional months 
(MIS 5-8, which occur exactly one year after MIS 1-4). ${ }^{4}$ The majority of the interviews in MIS1 and MIS-5 are conducted in person, with about 20 percent conducted by telephone; most of the interviews in the other months are conducted by telephone, with about 15 percent conducted in person. The response rate to the main interview averages more than 90 percent.

A volunteering supplement has been administered to CPS sample members each September since 2002. The supplement is administered after the main interview, either in English or in Spanish, and asks about all household members age 15 and older. In the September 2003 supplement, information was collected for 95,337 individuals. The overall response rate (main interview response rate multiplied by supplement response rate) was 81 percent.

The first two questions in the 2003 supplement were:

Since September $1^{\text {st }}$ of last year, have [you/NAME] done any volunteer activities through or for an organization? IF NO: Sometimes people don't think of activities they do infrequently or activities they do for children's schools, or youth organizations as volunteer activities. Since September $1^{\text {st }}$ of last year, have [you/NAME] done any of these types of volunteer activities?

Respondents who replied affirmatively were then asked for the number of organizations for which volunteer work was done, and the numbers of weeks and hours per week worked for each organization (or, if the respondent said the hours per week varied, the number of hours for the year).

\section{American Time Use Survey (ATUS)}

The American Time Use Survey (ATUS), an annual survey begun in 2003, is also conducted by the U.S. Census Bureau for the Bureau of Labor Statistics. The ATUS sample is chosen randomly from households participating in the CPS. As noted above, households

\footnotetext{
${ }^{4}$ The CPS tracks dwelling units, not individuals or households. Thus, as individuals move into or out of the dwelling unit, they will move into and out of the CPS sample. For other details of the survey, see Bureau of Labor Statistics and U.S. Census Bureau (2002).
} 
selected for the CPS are in the sample for a total of eight months, consisting of four consecutive calendar months (MIS 1-4) followed by the same four calendar months a year later (MIS 5-8). In any given month, approximately one-eighth of the CPS sample is in its final month (MIS-8). The ATUS sample is selected from households that successfully complete the MIS-8 main interview (about 93 percent of the MIS-8 sample do so). One randomly chosen individual age 15 years or older from each selected household is designated for ATUS participation. The ATUS sample is selected proportional to a state's population (thereby offsetting the CPS oversampling of residents of small states). In addition, households with an Hispanic or non-Hispanic black householder, as well as households with children, are oversampled. We correct for the oversampling by using selection weights in our analyses.

ATUS interviews are distributed across the weeks of the year, with random allocations to reporting days: one-quarter Saturdays, one-quarter Sundays, and one-half spread equally across the five weekdays. The interviews are administered by telephone, either in English or in Spanish. The roughly 5 percent of the sample for whom no telephone number is available are sent a letter asking them to call a toll free number on a specified day and offered a $\$ 40$ incentive for doing so. Respondents are asked to describe their primary activities, and how long each lasted, from 4:00 a.m. the previous day until 4:00 a.m. the interview day. After the 24 hours are accounted for, respondents are asked whether they did any "volunteer activities for or through an organization" during the day and those who say "No," are prompted with "Sometimes people don't think of activities they do for schools, or youth, or religious organizations as volunteer activities." Anyone answering affirmatively is then asked "Which of the activities you told me about were volunteer activities?”

Attempts to contact individuals for the ATUS begin about two months after the household's final CPS interview and continue for up to eight successive weeks. To minimize the 
lag between the September 2003 Volunteering Supplement responses and the ATUS response outcome, we use only the random subsample of cases that were MIS 5-8 in September 2003 (i.e., those whose final CPS interview took place in September, October, November or December 2003). Some of these 2003 Volunteering Supplement respondents were selected for the 2003 ATUS and some for the 2004 ATUS.

Of the 95,337 individuals 15 or older for whom information was collected in the September 2003 CPS Volunteering Supplement, there were 9,004 subsequently selected for the ATUS who were MIS 5-8 in September 2003. The ATUS weighted response rate for these cases was 57 percent. $^{5}$ Accounting for the non-response to the CPS MIS-8 basic interview (as noted above, about 93 percent of the sample completed that interview), the effective response rate for the ATUS cases in our sample was about 53 percent. This is just slightly above the response rates for the entire ATUS. ${ }^{6}$

The Bureau of Labor Statistics provides joint ATUS-CPS files that contain identifying information from the ATUS and a battery of demographic and labor force participation items from the CPS final interview (MIS-8). ${ }^{7}$ We merged these variables with the appropriate year's ATUS interview files (2003 or 2004) and then linked the resulting file to the September 2003 CPS supplement file.

\footnotetext{
${ }^{5}$ Ignoring the unequal probabilities of selection (e.g., households with children were oversampled), yields an unweighted response rate for these cases of 56 percent.

${ }^{6}$ In 2003, a total of 20,720 ATUS interviews were completed, for a weighted response rate of 54 percent. Budget cuts reduced the total number of interviews to 13,973 in 2004, for a weighted response rate of 53 percent. Accounting for nonresponse to the MIS-8 CPS interviews, these figures imply effective response rates of about 50 percent. The slightly higher response rate in our subsample dovetails with those cases having completed the September Volunteering Supplement, whereas other cases selected for the ATUS were either nonrespondents to the Supplement or not in the September sample. On the calculation of response rates, see Abraham, Maitland and Bianchi (2006). For other survey details see Bureau of Labor Statistics and U.S. Census Bureau (2005).

${ }^{7}$ We compared these variables as measured in the final month in sample and in the month of the Volunteering Supplement, and generally found little change. The one exception is labor force participation, which shows movement mainly between adjacent categories of hours worked.
} 
Although the results presented in this article are based on MIS 5-8 cases from the 2003 CPS Volunteering Supplement that became part of the 2003 or 2004 American Time Use Survey, we also conducted an analysis of MIS 5-8 cases from the 2002 CPS Volunteering Supplement that became part of the 2003 ATUS. That analysis yielded conclusions that are identical to those we present here.

\section{METHODS}

Our analysis begins with September 2003 CPS Supplement univariate and bivariate distributions of volunteer activity for individuals later selected for the ATUS. These analyses are augmented by multivariate models of the decision to volunteer and of the choice regarding how many hours to volunteer. If the same factors determine the two decisions, a Tobit specification might be appropriate for explaining both outcomes (Tobin 1958). Formally, the Tobit model can be written:

$$
\begin{aligned}
& y_{i}^{*}=x_{i} \beta+u_{i}, i=1,2, \ldots, n \\
& y_{i}=y_{i}^{*} \text { if } y_{i}^{*}>\alpha \\
& y_{i}=0 \text { if } y_{i}^{*} \leq \alpha
\end{aligned}
$$

where $\mathrm{y}_{\mathrm{i}}^{*}$ is a latent variable that is observable only when its value lies above a censoring threshold, $\mathrm{y}_{\mathrm{i}}$ is the observed variable, $\mathrm{x}_{\mathrm{i}}$ is a vector of explanatory factors, $\beta$ is a vector of coefficients, $\alpha$ is the censoring threshold, and $\mathrm{u}_{\mathrm{i}}$ is a residual that is assumed to be independent and identically distributed (i.i.d.) from a normal distribution with mean zero and variance $\sigma^{2}$. In our case, $\mathrm{y}_{\mathrm{i}}^{*}$ would be the latent propensity to volunteer, with actual volunteer hours $\mathrm{y}_{\mathrm{i}}$ equal to $\mathrm{y}_{\mathrm{i}}^{*}$ when $\mathrm{y}_{\mathrm{i}}^{*}>0$ and equal to 0 otherwise. Although the Tobit specification has some appeal, a 
formal test strongly rejected its assumption that a single set of parameters can explain both the decision to volunteer and the number of hours volunteered. ${ }^{8}$

A more flexible alternative specification is a two-part model of the sort proposed by Cragg (1971). In the two-part model, a logit or probit equation is used to model whether or not a behavior of interest occurs, and a separate regression equation is used to model the intensity of the behavior for those who engage in it. Two-part models have been used, among other applications, to study spending on consumer durables (Cragg, 1971), vacation spending (Melenberg and Van Soest, 1996), and the demand for cigarettes (Raptou et al., 2005), and frequently are employed by health economists interested in explaining health care outcomes and medical care spending (see, for example, Duan et al 1983). All of these applications have in common that different factors are believed to determine an outcome's incidence (positive versus zero) as opposed to its intensity (the positive values' magnitude). In our analysis, we use a probit equation to model whether or not a person reports any volunteer activity, and an ordinary least squares regression to model hours of volunteer activity for those who report volunteering.

Noting that:

$$
\mathrm{E}(\mathrm{y} \mid \mathrm{X})=\mathrm{P}(\mathrm{y}>0 \mid \mathrm{X}) \mathrm{x} \mathrm{E}(\mathrm{y} \mid \mathrm{y}>0, \mathrm{X})
$$

the effect of the change in any explanatory variable on average volunteer hours can be written as:

$$
\text { (3) } \frac{\delta E(y)}{\delta X_{c}}=\frac{\delta P(y>0)}{\delta X_{c}} x E(y \mid y>0, X)+\mathrm{P}(\mathrm{y}>0 \mid \mathrm{X}) x \frac{\delta E(y \mid y>0)}{\delta X_{c}}
$$

In this equation, the first term on the right-hand side represents the effect on overall average volunteer hours due to the change in the probability of volunteering and the second term represents the effect due to the change in average volunteer hours among those who volunteer.

\footnotetext{
${ }^{8}$ See Greene (2003: 770), for details concerning the test of the Tobit model restrictions.
} 
Unless otherwise stated, all the estimates we report in this paper were calculated using ATUS selection (i.e., base) weights. ${ }^{9}$ Standard errors were calculated using a replicate variance method proposed by Fay (1989) that accounts for the increase in variance associated with the clustering and weighting in the ATUS sample relative to the variance that would be expected in a simple random sample of the same size. The replicate weights we used to implement this procedure were provided by the Bureau of Labor Statistics. The DESCRIPT procedure in SAScallable SUDAAN was used to compute the standard errors reported in Tables 1,2 and 4, and also to carry out tests of statistical significance for differences in estimates across subgroups. Stata software (SVY) was used to estimate the multivariate models and associated standard errors reported in Table 3.

\section{RESULTS}

\section{CPS Univariate Estimates of Volunteering}

We begin by comparing the volunteering reports from the entire CPS supplement sample to those from our overlap subsample (which, two to eight months later, became ATUS respondents or nonrespondents). Comparing the first two rows of Table 1, we see that the estimates from the overlap sample are very close to those from the full sample. About 29 percent of each group reported having volunteered in the past year, and the average volunteer time reported by the two groups was very similar (37.9 hours versus 37.4 hours). The estimate of mean hours among those who did any volunteering also is very similar for the two groups (131.4 in the overlap subsample versus 129.8 hours in the full sample). In each case, the estimated value for our overlap sample is statistically indistinguishable from that for the CPS Supplement respondents who were not selected for the ATUS.

\footnotetext{
${ }^{9}$ Since our aim is to assess nonresponse bias, we chose not to use the ATUS final weights that incorporate poststratification, which is intended to adjust for nonresponse. In fact, as already noted, our findings imply that poststratification will not correct for the nonresponse bias in the volunteering estimates.
} 


\section{TABLE 1 ABOUT HERE}

The third and fourth rows of Table 1 show that individuals who became ATUS respondents were over 75 percent more likely than those who became ATUS nonrespondents to report in the CPS that they had done volunteer work: 36 percent versus 20 percent. Likewise ATUS respondents reported an average of over 75 percent more hours worked as a volunteer than did ATUS nonrespondents: 46.6 hours versus 26.4 hours. The second finding is entirely a function of the first - among those who said they had volunteered, there is no difference between respondents and nonrespondents in the average number of volunteer hours. ${ }^{10}$

The remaining rows of Table 1 disaggregate the nonrespondents into five subgroups: two for which telephone contact was not undertaken (because the respondent had moved away or no valid phone number for the household was available); one that was not successfully contacted (despite good contact information); one that refused; and a residual group, which consisted largely of individuals who spoke neither English nor Spanish. All five groups had much lower rates of volunteering than did respondents, but there were differences among the groups.

ATUS contacts are not attempted with individuals who no longer live at the address at which the CPS interview was conducted nor were in-person interviews attempted for those individuals for whom good telephone contact information was lacking. These two groups show lower rates of volunteering than do unsuccessful contacts and refusals, and the volunteering rates of the "other" (mainly language barrier) group are even lower. We interpret these results in terms of social integration: Geographical mobility, lacking phone service, and speaking neither English nor Spanish are all indicators of weak social integration. The differences between the

\footnotetext{
${ }^{10}$ Interviewers were instructed to try to conduct CPS Supplement interviews with each household member, but proxy reports were accepted where that was not feasible. As a check on whether proxy reports affected our results, we redid the analyses including only single person households, in which proxy reports are not possible. As with the full sample, we find that respondents are about 15 percentage points more likely to volunteer than nonrespondents and that, as a result, they have higher average volunteer hours.
} 
two remaining groups, refusals and unsuccessful contacts, are not statistically significant.

Though both show significantly higher rates of volunteering than other nonrespondents, their volunteering rates are still much lower than those of respondents. ${ }^{11}$

\section{CPS Bivariate Estimates of Volunteering}

The conventional approach to dealing with nonresponse bias is some form of statistical adjustment based on weighting classes, propensity models or a related technique. As noted by Groves (2006: 653), however, "All of these adjustment techniques require assumptions that groups of respondents and nonrespondents share response propensities and distributional properties on survey measures." To the extent that respondents and nonrespondents within a weighting class do not share the same expected values on the survey variable, the adjustment will fail. Unlike the typical situation in which this assumption is untestable, we can examine whether the CPS volunteering reports of ATUS respondents and nonrespondents are the same within subclasses of background variables that have been shown to be related to volunteering.

Wilson and Musick (1997; see also Musick, Wilson, and Bynum, 2000) argue that volunteering is a function of three kinds of resources: human capital, social capital and cultural capital. The CPS has no measures of cultural resources, but it does contain indicators of both human capital and social capital, as well as other background characteristics. Our principal measure of human capital is educational attainment, which we supplement with household income as a rough proxy for unobserved skills that may affect earnings power. The CPS contains six measures that we use as indicators of social capital: being in the labor force, being married, living in a household with children, living in a household that includes no adults other

\footnotetext{
${ }^{11}$ The differences among the five nonrespondent groups in hours volunteered parallel the differences in volunteering rates, though because the standard errors of these estimates are relatively larger the differences are generally not statistically significant. Among those who claimed to have volunteered, the differences in average hours between respondents and each of the nonrespondent groups is statistically insignificant (with the exception of the "other" group).
} 
than immediate family members, living in a home that is owned rather than rented, and living in a household with a telephone. Finally, we account for five background characteristics: sex, age, race/ethnicity, urbanicity and region of residence. Taken together, these constitute a potentially rich set of variables for nonresponse adjustment.

\section{TABLE 2a ABOUT HERE}

The second column in Table 2a shows that human capital, social capital, and other background variables are related to rates of volunteering in the expected ways. For example, individuals with more education are more likely to report volunteering, as are those with higher incomes, married people, those with school-age children, homeowners, women, and nonHispanic non-blacks.

The more important result in Table $2 \mathrm{a}$ is that, within every subgroup, respondents report higher volunteering rates than nonrespondents. There is some variation in the size of the difference (e.g., the difference is larger for older respondents than for younger ones), but the most striking aspect of the table is the extent to which nonrespondents are distinctive. In 51 of the 52 subgroups, the volunteering rate among respondents is at least 25 percent greater than among nonrespondents (and in 49 cases it is at least 40 percent higher). This is compelling evidence against the assumption that respondents and nonrespondents within subclasses share the same expected values on volunteering.

Table $2 \mathrm{~b}$ presents the same analysis, substituting overall average volunteer hours for volunteer rates. The second column generally shows the expected associations between hours and the independent variables. Individuals who are better educated and those who have higher incomes report more volunteer hours, as do married people, homeowners, women, and nonHispanic non-blacks. More importantly, in 50 of the 52 subgroups, respondents report higher levels of mean volunteer hours than do nonrespondents, and the difference in reported hours 
between respondents and nonrespondents is not statistically significant in the two cases where the reverse is true.

\section{TABLE $2 b$ ABOUT HERE}

The fact that the volunteering difference between respondents and nonrespondents is similarly large within subgroups is bad news for univariate analyses, because it means that statistical adjustment for nonresponse based on observable demographic or other background characteristics of the sample members will not correct the bias in the estimate of the overall amount of volunteering in the population. But it is good news for bivariate (and possibly, multivariate) analysis. If the nonresponse bias is approximately constant across subgroups, inferences about the relationships between volunteering and the variables used to define the subgroups will be relatively unaffected. That is, although the level of volunteering will be exaggerated, it will be exaggerated to about the same extent across subgroups, and thus estimates of the differences between subgroups will be little affected.

Although comparing the second and fourth columns in Tables $2 \mathrm{a}$ and $2 \mathrm{~b}$ indicates that the bivariate associations are generally immune to nonresponse bias, given the interrelationships among the variables we would like to know whether the same can be said about multivariate analyses.

\section{CPS Multivariate Estimates of Volunteering}

In this section, we estimate multivariate models of volunteering using the human capital, social capital, and other demographic indicators, first for the full ATUS overlap sample and then for the subsample of ATUS respondents. Adding a dummy variable distinguishing ATUS respondents and nonrespondents to the full sample model allows us to test whether nonresponse has a significant impact on estimates after simultaneously controlling for all the other characteristics. Comparison of the full sample and ATUS respondent models allows us to test 
whether inferences about the factors that affect volunteering are robust to nonresponse. To the extent that coefficients in the model including only respondents differ from those in the model based on the full sample, nonresponse bias affects multivariate inference. To the extent that coefficients in the model are not altered as we move from the full sample to the respondents-only sample, multivariate inferences are not compromised by nonresponse bias.

The first three columns in Table 3 summarize the results of using the full sample to estimate a two-part multivariate volunteering model. The first column of the table, from a probit analysis of the propensity to volunteer, shows the percentage point change in the volunteering rate associated with having the particular indicated characteristic rather than the full base set of characteristics. $^{12}$ The coefficients in the second column, from an ordinary least squares regression, show the effects of the same characteristics on annual volunteer hours among those who volunteer. Drawing on equation (3), the two sets of coefficients can be used in conjunction with the estimates of the volunteer rate $[\mathrm{P}(\mathrm{y}>0 \mid \mathrm{X})]$ and of volunteer hours among those who volunteer $[E(y \mid y>0, X)]$ to estimate the effects of each variable on overall average volunteer hours (for a person with the base group characteristics). These estimates are shown in the third column of Table 3 .

\section{TABLE 3 ABOUT HERE}

As can be seen in the first column of Table 3, most of the explanatory variables are significantly related to the propensity to volunteer. The differences among groups generally parallel those observed in the bivariate results (Table 2a), but tend to be smaller (as would be expected given the intercorrelations among the independent variables). The main exception involves the association between marital status and the propensity to volunteer: The higher

\footnotetext{
${ }^{12}$ The reference person is defined by the modal category of each characteristic. She is a married female nonHispanic non-black high school graduate age 31-45 who lives in the south and owns a home in the suburbs that has telephone service. She is not in the labor force and has an annual household income in the range \$20,000-\$39,999. She has no children or non-immediate family members resident in the household.
} 
volunteering rate among married respondents shown in Table 2a reflects these individuals' other characteristics rather than their marital status.

In contrast, the multivariate model reveals that only a few characteristics are significantly related to volunteer hours among those who volunteered (second column of Table 3). Among volunteers, those who had not graduated from high school and those without telephone service reported fewer hours, and those older than 65 reported more hours. In addition, compared to volunteers not in the labor force, those who worked less than 45 hours per week reported fewer hours. (The remaining statistically significant effect, for cases whose urbanicity was missing, is based on only 6 respondents.)

These results are not comparable to the bivariate results in Table $2 \mathrm{~b}$ since they are based only on respondents who volunteered, whereas Tables $2 \mathrm{~b}$ includes all respondents. The estimates in the third column of Table 3, which show the effects on overall volunteer hours, can be compared to the bivariate estimates reported in Table $2 \mathrm{~b}$. The two sets of results are generally similar, with education, income, presence of school-age children, and not having a telephone in the household associated with sizeable differences in volunteer hours. Except for the difference associated with household telephone status, these large differences in average volunteer hours are due primarily to differences in volunteer rates rather than hours worked among those who volunteer (the difference by household telephone status reflects both of these effects).

By adding a dummy variable for whether a person is an ATUS respondent to the volunteer rate and volunteer hours equations reported in the first two columns of Table 3 , we can measure the degree to which ATUS respondents differ from ATUS nonrespondents in their reported volunteer behavior once all the background characteristics are held constant. The coefficient on the respondent dummy variable in the volunteer propensity equation is highly significant and indicates that, among those with the reference set of personal characteristics, 
respondents are 10 percentage points more likely to volunteer than nonrespondents. This effect is two-thirds the size of the 15 percentage point differential in volunteering propensities documented in Table 1 without accounting for differences in the observable characteristics of respondents and nonrespondents. As was true absent controls for other characteristics, conditional on volunteering, the hours reported by respondents do not differ significantly from those reported by nonrespondents. Taken together, the two sets of coefficient estimates imply that, all else the same, respondents volunteer annually an average of about 13 hours more than nonrespondents. $^{13}$

By comparing the results in the last three columns of Table 3 with those in the first three columns, we can assess the extent to which using data for respondents alone affects the multivariate associations between volunteering and the background characteristics. Consistent with the message of Tables $2 \mathrm{a}$ and $2 \mathrm{~b}$, the exclusion of the nonrespondents has little impact on multivariate inferences. The coefficients in the "respondent" models generally are very similar to those in the "full sample" models. As a more formal test, we compared models estimated for the full sample that contained all of the background characteristics plus a dummy variable for whether the person was an ATUS respondent to a series of models that added interactions between the ATUS respondent dummy and selected background variables. The first of these alternate models added interactions between the respondent dummy and the four education dummies, the second added interactions with the four household income dummies, and so on. For eight of the sets of background variables (labor force status, marital status, children in the household, others in the household, telephone service, sex, urbanicity and region) the interaction terms were not statistically significant, and in none of the five cases in which they were

\footnotetext{
${ }^{13}$ Adding the ATUS response dummy variable to these equations has little effect on the coefficients estimated for the other characteristic variables. Full results are available upon request.
} 
statistically significant (education, income, housing tenure, race and age) do the qualitative inferences to be drawn about the relationship between volunteering and the background characteristic differ between the full versus respondent samples.

\section{ATUS Estimates of Volunteering}

To this point we have reported volunteering estimates from the CPS. Among those in the overlap sample who said in the CPS that they had volunteered, 70 percent became ATUS respondents compared to just 52 percent of those who said they had not volunteered. Our expectation is that this differential nonresponse will (a) cause the ATUS volunteering estimates to be too high, but (b) will not affect the ATUS estimates of volunteering's correlates.

Unlike the CPS (which has a twelve-month reporting period), the single day reporting period of the ATUS means that the ATUS cannot produce a meaningful estimate of the proportion of volunteers. The ATUS can, however, produce a meaningful estimate of mean annual volunteer hours that we can compare to the CPS hours estimate. For this estimate we use the entire ATUS sample, not just those sample members who had previously participated in the September 2003 Volunteering Supplement. The first step in constructing the ATUS estimate of mean annual hours is to calculate the weighted mean of the hours reported by survey respondents on their diary day, using the ATUS sample (base) weights adjusted to account for the differing probabilities of assignment to weekday versus weekend days. Multiplying this estimate of mean daily volunteer hours by 365 yields an estimate of mean annual volunteer hours. We compare estimates from the CPS supplement that refer to the September 2002-September 2003 period to ATUS estimates for calendar year 2003. ${ }^{14}$

\footnotetext{
${ }^{14}$ Though the two estimates cover slightly different time periods, both cover a full calendar year and, given that the 2004 CPS volunteering supplement produced results almost identical to those from the 2003 supplement, we have no reason to believe that the discrepancy between the starting dates for the two reference periods should have significantly affected the findings.
} 
As noted earlier, the CPS estimate of average volunteer hours for the period September 2002 to September 2003 is 37.4 hours for the full ATUS overlap sample and 46.6 hours for the ATUS respondents among that group (Table 1). If there were no other differences between the surveys, we might therefore expect the estimate for the calendar year 2003 ATUS sample to be within sampling error of 46.6 hours. In fact, the ATUS estimate of mean volunteer hours for calendar year 2003 is slightly higher, at 53.5 hours with a standard error of 2.2 hours (Table 4$).{ }^{15}$ Although the ATUS estimate of volunteer hours suffers from substantial nonresponse bias that makes it much too high, the CPS estimate might suffer from recall error due to the difficulty of the twelve-month recall task (leading to a downward bias) and from social desirability bias (leading to an upward bias). Since the ATUS is not apt to suffer significantly from either of these two error sources, the fact that the ATUS estimate is a little higher than the CPS estimate based on ATUS respondents suggests that recall error is a somewhat larger problem for the CPS estimates than social desirability bias. ${ }^{16}$

\section{TABLE 4 ABOUT HERE}

\footnotetext{
${ }^{15}$ We can also compare the 2003 CPS estimate for ATUS respondents (46.6 hours with a standard error of 2.6 hours) to the ATUS estimate for the same respondents (58.2 hours with a standard error of 4.5 hours), but this comparison is more severely compromised by different reference periods. All of the interviews with ATUS respondents who completed the CPS supplement occurred between November 2003 and May 2004, with most completed between December 2003 and March 2004. To the extent that volunteering is seasonal, ATUS estimates based on interviews conducted during the December through March period may differ from estimates based on interviews conducted across the whole calendar year. Further, this comparison does not benefit from overlap between the CPS and ATUS reference periods.

${ }^{16}$ The ATUS and the CPS also differ in that about 5 percent of ATUS respondents were paid a $\$ 40$ incentive to participate (compared to no respondents being paid in the CPS) and all the ATUS interviews were conducted by telephone whereas about 30 percent of the CPS interviews were conducted in person. Although ATUS respondents who received incentives to participate reported less volunteer activity than other respondents, excluding them from the analysis changes none of our conclusions. To assess the effect of telephone versus in person administration on reports of volunteer activity, we compared estimates based on the full CPS supplement sample for respondents in MIS-1 and MIS-5, most of whom were interviewed in person, with estimates for respondents in MIS 2-4 and MIS 68 , most of whom were interviewed by phone. MIS-1 and MIS-5 respondents were a little more likely to report volunteering than other respondents (32.1 percent versus 30.0 percent and 43.7 hours versus 38.2 hours) but this difference may reflect a month-in-sample effect rather than a mode effect.
} 
Table 4 also shows that, although the ATUS estimate of average volunteer hours is much larger than that from the full CPS sample, the ATUS estimates of the associations between respondent background characteristics and volunteer hours are similar to those from the CPS (Table 2b). Thus at least in this case conclusions about the determinants of volunteering are generally unaffected by nonresponse. ${ }^{17}$

\section{DISCUSSION}

The large variation in survey estimates of volunteering (including those from the CPS volunteering supplement) might plausibly be attributed to measurement error - the difficulty respondents have recalling an entire year's activities and respondent exaggeration in reporting the extent of their volunteering. These concerns about the quality of responses to volunteering questions led scholars eagerly to await the American Time Use Survey, which provides volunteering estimates that are unlikely to suffer from major recall error or motivated misreporting. With this in mind, Abraham and Mackie (2005: 147) wrote that "When they become available, data on volunteer activity from the new American Time Use Survey (ATUS) should be more reliable than any that currently exist." Our results, however, indicate that although the ATUS estimates may be less susceptible to measurement error than the CPS volunteering supplement estimates, this is outweighed by the much greater nonresponse error in the ATUS estimates.

We believe our finding of nonresponse bias in the ATUS sample has implications for all surveys of volunteering. In our introduction, for instance, we noted the discrepancy in volunteering rates between the 1996 National Household Education Survey (NHES; National

\footnotetext{
${ }^{17}$ Our inferences about the impact of ATUS nonresponse are based on the characteristics of those ATUS nonrespondents (about four-fifths) for whom we have CPS Volunteering Supplement observations. The remaining ATUS nonresponse overlaps with nonresponse to the CPS Supplement. It seems very likely that the latter nonrespondents (for whom we have no data) are also disproportionately nonvolunteers, but to the extent this is incorrect it could compromise our conclusions.
} 
Center for Education Statistics, 1997) and the 2002 CPS Supplement (Boraas, 2003). The higher volunteering rate in the 1996 NHES ( 39 percent) as compared to the 2002 CPS supplement (28 percent) is entirely consistent with the two surveys' relative response rates (59 percent versus 81 percent).

Similarly, the volunteering rate of 55 percent from Grimm et al.'s (2005) survey of teenagers is likely a function of that survey's relatively low response rate (44 percent). Thus Grimm et al.'s conclusion that teenagers volunteer at a rate "more than one and a half times the adult rate of 29 percent as established by the...2004 Current Population Survey figures, which used the same questions and definitions as the Youth Volunteering Survey" is almost surely wrong. The difference is most likely a function of nonresponse bias - that is, of teenagers who were not volunteers being much less likely to participate (the CPS shows that teenagers are less apt to volunteer than are middle-aged adults). ${ }^{18}$

If we are correct that our results are due to the strong connection between the causes of volunteering and the causes of survey participation, then surveys also will tend to overestimate other prosocial activities. Three prior studies provide evidence along these lines. Couper, Singer, and Kulka (1998) found that households in which respondents said they participated in community activities were more likely to have returned their decennial census form than households in which respondents said they did not participate in such activities. Groves, Singer, and Corning (2000) reported that the response rate to a mail survey was higher among those who had scored high on an index of community involvement in an earlier survey than among those who had scored low (but only for the half sample that did not receive a $\$ 5$ prepaid incentive).

\footnotetext{
${ }^{18}$ Parental permission is required for the Youth Volunteering Survey, and according to one of the Grimm et al., coauthors, parental refusals are the survey's main source of nonresponse (N. Dietz, personal communication). Although a growing number of high schools require students to meet "volunteer" service hours requirements in order to graduate, fewer than a quarter of high school students were subject to such a requirement in 1999, the most recent year for which we have been able to locate this information (Kleiner and Chapman, 1999).
} 
And Kennickell (2005) found that individuals who declared larger charitable contribution deductions on their federal income tax return were more likely to be respondents in the Survey of Consumer Finances than those who declared smaller deductions. Although these studies generally focused on the effect of a prosocial behavior on nonresponse, without addressing the corresponding issue of nonresponse's impact on estimates of the prosocial behavior, they all suggest that nonresponse will lead to overestimating such behaviors. ${ }^{19}$

To the extent that the size of the nonresponse bias in volunteering (and other prosocial activities) is affected by the level of nonresponse, the secular decline in response rates means that inferences about changes over time in volunteering (and prosocial behaviors more generally) are apt to be distorted by the bias. Estimates of volunteering likely have increased over time (see Figure 1) because the composition of samples changed as response rates declined. This seems to be the most compelling explanation for why trends in volunteering over the last several decades are so different from trends in other dimensions of social capital (Putnam 2000: 127).

Researchers commonly rely on weights to correct for differential nonresponse across different groups of sample members. Such weighting will ameliorate nonresponse bias only to the extent that the characteristics used to make the weighting adjustments are correlated both with the propensity to respond and with the variables of interest. Because there are significant differences in volunteering between respondents and nonrespondents even after controlling for a rich set of demographic characteristics, standard weighting adjustments cannot be relied upon to fix the problem with estimates of volunteering. This is apt also to be the case for other prosocial behaviors.

\footnotetext{
${ }^{19}$ Although the evidence is more indirect, Robinson (1989) suggests that surveys are also apt to overestimate participation in the arts because those who engage in such activities are more likely to participate in surveys than those who don't engage in the arts.
} 
The importance of volunteering as a determinant of response propensity, however, suggests a strategy to improve weighting adjustments in other survey contexts. Specifically, our findings suggest that there is an important element of altruism in the decision about whether to respond to a survey request. If the two basic CPS questions about volunteering were routinely added to household surveys, that information could be used together with information from the CPS volunteering supplements to create weighting adjustment factors that account for the share of volunteers in the survey sample relative to the population share. The inclusion of volunteering as a determinant of response propensity in the nonresponse weighting process should be particularly helpful for improving estimates of other prosocial behaviors that one would expect to be strongly correlated with volunteering, but also would improve the estimate of any variable correlated with volunteering.

Although our findings have troubling implications for research on the amount of volunteering, on trends in volunteering over time, and on the usefulness of conventional statistical adjustments based on the demographic characteristics of respondents to correct the problems, the implications are more comforting for research on the characteristics of individuals associated with volunteering. Our results suggest that bivariate and multivariate inferences about the relationship of volunteering (and likely other prosocial activities) to respondent characteristics are relatively immune to nonresponse bias. In this sense, the results resemble the pattern of "form-resistant correlations," the tendency for changes in survey question wording that affect univariate distributions not to affect bivariate or multivariate distributions (Schuman and Presser, 1981). The findings presented here suggest the same may be true of nonresponse. Studies with measures other than volunteering are needed to determine the extent to which this applies to survey estimates in general. 


\section{REFERENCES}

Abraham, K., and C. Mackie (eds.). 2005. Beyond The Market: Designing Nonmarket Accounts for the United States. Washington DC: National Academies Press.

Abraham, K., A. Maitland and S. Bianchi. 2006. "Nonresponse in the American Time Use Survey: Who is Missing from the Data and How Much Does It Matter?" Public Opinion Quarterly 70: 676-703.

Boraas, S. 2003. "Volunteerism in the United States," Monthly Labor Review 126: 3-11.

Bureau of Labor Statistics and U.S. Census Bureau. 2002. Current Population Survey: Design and Methodology. Technical Paper 63RV.

Bureau of Labor Statistics and U.S. Census Bureau. 2005. American Time Use Survey User's Guide: 2003-2004. [http://www.bls.gov/tus/atususersguide.pdf]

Cragg, J.G. 1971. "Some Statistical Models for Limited Dependent Variables with Application to the Demand for Durable Goods," Econometrica, 39(5): 829-844.

Couper, M., E. Singer, and R. Kulka. 1998. "Participation in the 1990 Decennial Census," American Politics Quarterly 26: 59-80.

Curtin, R., S. Presser, and E. Singer. 2005. "Changes in Telephone Survey Nonresponse over the Past Quarter Century," Public Opinion Quarterly 69: 87-98.

Curtin, R., S. Presser, and E. Singer. 2000. "Effects of Response Rate Changes on the Index of Consumer Sentiment," Public Opinion Quarterly 64: 413-428.

Duan, N., W. Manning, C.N. Morris, and J.P. Newhouse. 1983. "A Comparison of Alternative Models for the Demand for Medical Care," Journal of Business and Economic Statistics, 1(2): 115-126. 
Fay, R. 1989. "Theoretical Application of Weighting for Variance Calculation.” Proceedings of the Section on Survey Research Methods of the American Statistical Association, 212217.

Greene, W. 2003. Econometric Analysis. Upper Saddle River NJ: Prentice-Hall.

Grimm, R., N. Dietz, K. Spring, K. Arey, and J. Foster-Bey. 2005 "Building Active Citizens: The Role of Social Institutions in Teen Volunteering.” Washington, D.C.: Corporation for National and Community Service.

Groves, R. 2006. "Nonresponse Rates and Nonresponse Bias in Household Surveys." $\quad$ Public Opinion Quarterly 70: 646-675.

Groves, R., and R. Kahn. 1979. Surveys by Telephone. New York: Academic Press.

Groves, R., S. Presser, and S. Dipko. 2004. "The Role of Topic Interest in Survey Participation Decisions," Public Opinion Quarterly 68: 2-31.

Groves, R., E. Singer, and A. Corning. 2000. "Leverage Salience Theory of Survey Participation,” Public Opinion Quarterly 64: 299-308.

Hodgkinson, V. and M. Weitzman. 1996. Giving and Volunteering in the United States. Washington DC: Independent Sector.

Keeter, S., C. Miller, A. Kohut, R. Groves, and S. Presser. 2000. "Consequences of Reducing Nonresponse in a Large National Telephone Survey.” Public Opinion Quarterly 64: 125148.

Kennickell, A. 2005. "Darkness Made Visible: Field Management and Nonresponse Bias in the 2004 SCF.” Presented at the American Statistical Association Meeting.

Knack, S. 1992. "Civic Norms, Social Sanctions, and Voter Turnout," Rationality and Society 4: $133-156$. 
Kleiner, B. And C. Chapman. 1999. "Service Learning and Community Service Among 6ththrough 12th-Grade Students in the United States: 1996 and 1999.” Washington, DC: National Center for Education Statistics.

Melenberg, B. and A. Van Soest. 1996. "Parametric and Semi-Parametric Modelling of Vacation Expenditures," Journal of Applied Econometrics, 11(1): 59-76.

Merkle, D., and M. Edelman. 2002. "Nonresponse in Exit Polls: A Comprehensive Analysis.” Pp. 243-57 in Survey Nonresponse, ed. R. Groves, et al., New York: Wiley.

Musick, M., J. Wilson, and W. Bynum, Jr. June, 2000. “Race and Formal Volunteering: The Differential Effects of Class and Religion,” Social Forces 78: 1539-1570.

National Center for Education Statistics. 1997. Adult Civic Involvement in the United States. Washington DC: NCES 97-906.

Putnam, R. 2000. Bowling Alone. New York: Simon and Schuster.

Raptou, E., M. Konstatinos, E. Tsakiridou, and C. Katrakilidis. 2005. International Advances in Economic Research, 11: 275-290.

Robinson, J. 1989. "Survey Organization Differences in Estimating Public Participation in the Arts," Public Opinion Quarterly 53: 397-414.

Schuman, H., and S. Presser. 1981. Questions and Answers in Attitude Surveys. New York: Academic Press.

Tobin, J. 1958. "Estimation of Relationships for Limited Dependent Variables." Econometrica 26: 24-36.

Wilson, J. 2000. “Volunteering.” Annual Review of Sociology 26: 215-240.

Wilson, J., and M. Musick. 1997. "Who Cares? Toward an Integrated Theory of Volunteering." American Sociological Review 62: 694-713. 
Fig. 1. Percent Volunteers in Gallup Surveys

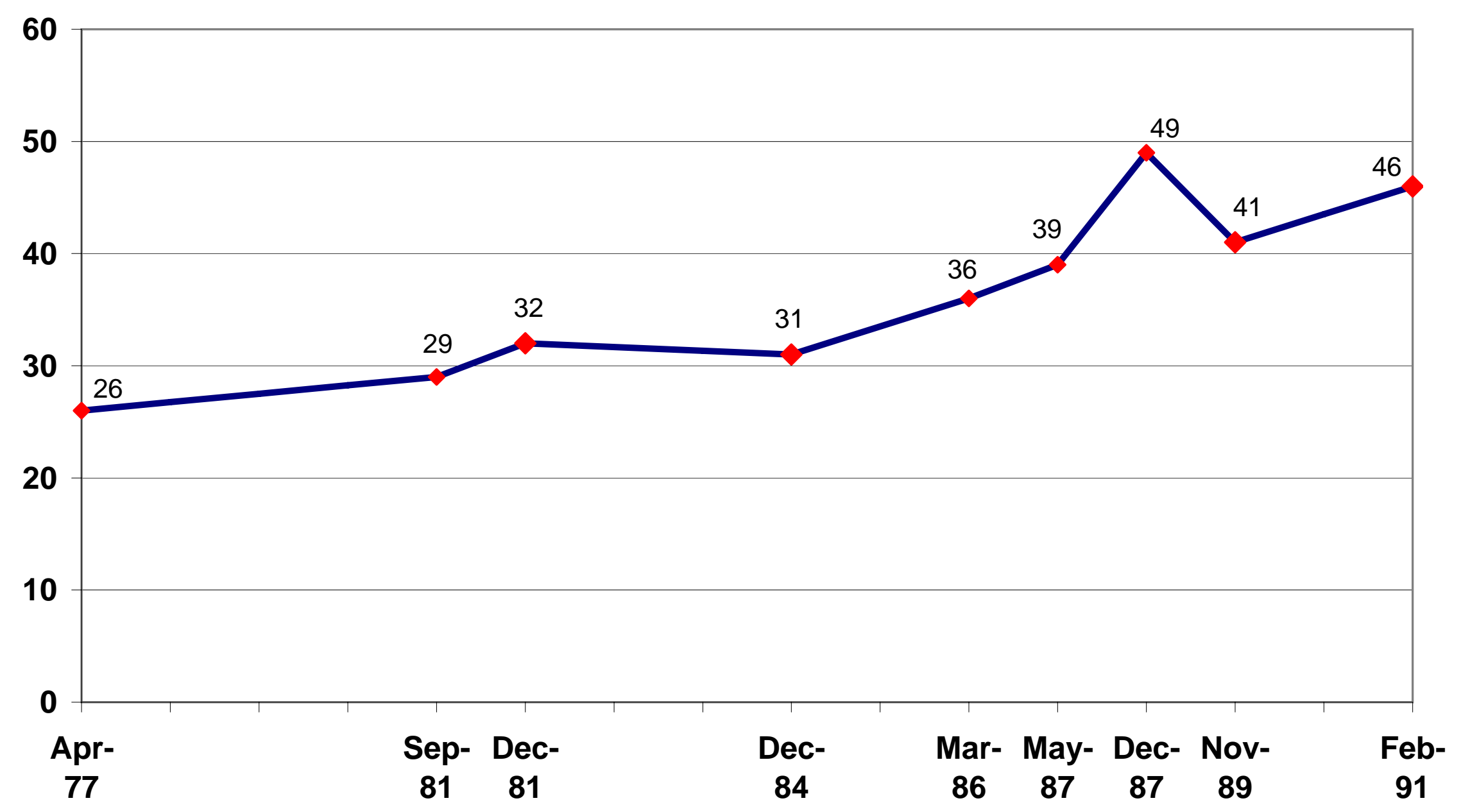

SOURCE: Roper Center Accession Nos. 0047361, 0031892, 0030064, 0032803, 0026314, 0026426, 0047980, 0028183, and 0236260 
TABLE 1: Volunteer rates and mean hours spent volunteering, September 2003 CPS Volunteer supplement, various samples

\begin{tabular}{|c|c|c|c|c|}
\hline & \multirow{2}{*}{$\begin{array}{c}\text { Percent } \\
\text { Who } \\
\text { Volunteer }\end{array}$} & \multicolumn{2}{|c|}{ Volunteer Hours } & \multirow[b]{2}{*}{$\mathrm{N}$} \\
\hline & & $\begin{array}{c}\text { Volunteer } \\
\text { Mean }\end{array}$ & $\begin{array}{c}\text { Overall } \\
\text { Mean }\end{array}$ & \\
\hline All volunteer supplement respondents & $\begin{array}{r}28.8 \\
(0.1)\end{array}$ & $\begin{array}{l}129.8 \\
(1.6)\end{array}$ & $\begin{array}{l}37.4 \\
(0.5)\end{array}$ & 95337 \\
\hline Volunteer supplement respondents in ATUS sample & $\begin{array}{l}28.9 \\
(0.6)\end{array}$ & $\begin{array}{r}131.4 \\
(5.2)\end{array}$ & $\begin{array}{l}37.9 \\
(1.7)\end{array}$ & 9004 \\
\hline ATUS respondents & $\begin{array}{l}35.5 \\
(0.8)\end{array}$ & $\begin{array}{r}131.3 \\
(6.5)\end{array}$ & $\begin{array}{l}46.6 \\
(2.6)\end{array}$ & 5079 \\
\hline ATUS nonrespondents & $20.1_{(0.8)}$ & $\begin{array}{l}131.6 \\
(10.1)\end{array}$ & $\begin{array}{l}26.4 \\
(2.2)\end{array}$ & 3925 \\
\hline Contact not attempted & 17.4 & $\begin{array}{l}137.3 \\
\quad(22.7)\end{array}$ & $\begin{array}{l}23.8 \\
(4.4)\end{array}$ & 946 \\
\hline Inadequate/missing contact information & 17.0 & $\begin{array}{l}124.6 \\
(22.6)\end{array}$ & $\begin{array}{l}21.2 \\
(4.1)\end{array}$ & 920 \\
\hline Unsuccessful contact & $\begin{array}{l}22.9 \\
(1.9)\end{array}$ & $\begin{array}{l}110.8 \\
\quad(18.2)\end{array}$ & $\begin{array}{l}25.3 \\
(4.7)\end{array}$ & 518 \\
\hline Refusals & 23.8 & $\begin{array}{r}139.4 \\
(4.0)\end{array}$ & $\begin{array}{r}33.2 \\
(4.0)\end{array}$ & 1439 \\
\hline Other & $\begin{array}{ll}6.7 & \\
& (3.2) \\
\end{array}$ & $\begin{array}{l}70.5 \\
\quad(28.4)\end{array}$ & $\begin{array}{l}4.7 \\
(2.3)\end{array}$ & 102 \\
\hline
\end{tabular}

Note: The column labeled "Volunteer Mean" reports annual hours among volunteers; the column labeled "Overall Mean" reports annual hours for the full sample, including those who did not volunteer. Hours were imputed for 143 individuals who reported that they volunteered but did not report the time they spent. Entries in the first row were calculated using the CPS supplement nonresponse weights and those in the remaining rows were calculated using the ATUS sample selection weights. Except in the first row, standard errors reported in parentheses have been adjusted to account for the clustering and weighting of the sample; the information necessary to make this adjustment for the first row is unavailable on the CPS supplement public use file. 
TABLE 2A: Volunteer rates calculated from the 2003 CPS volunteer supplement, full ATUS overlap sample, ATUS respondents and ATUS non-respondents, by selected background characteristics

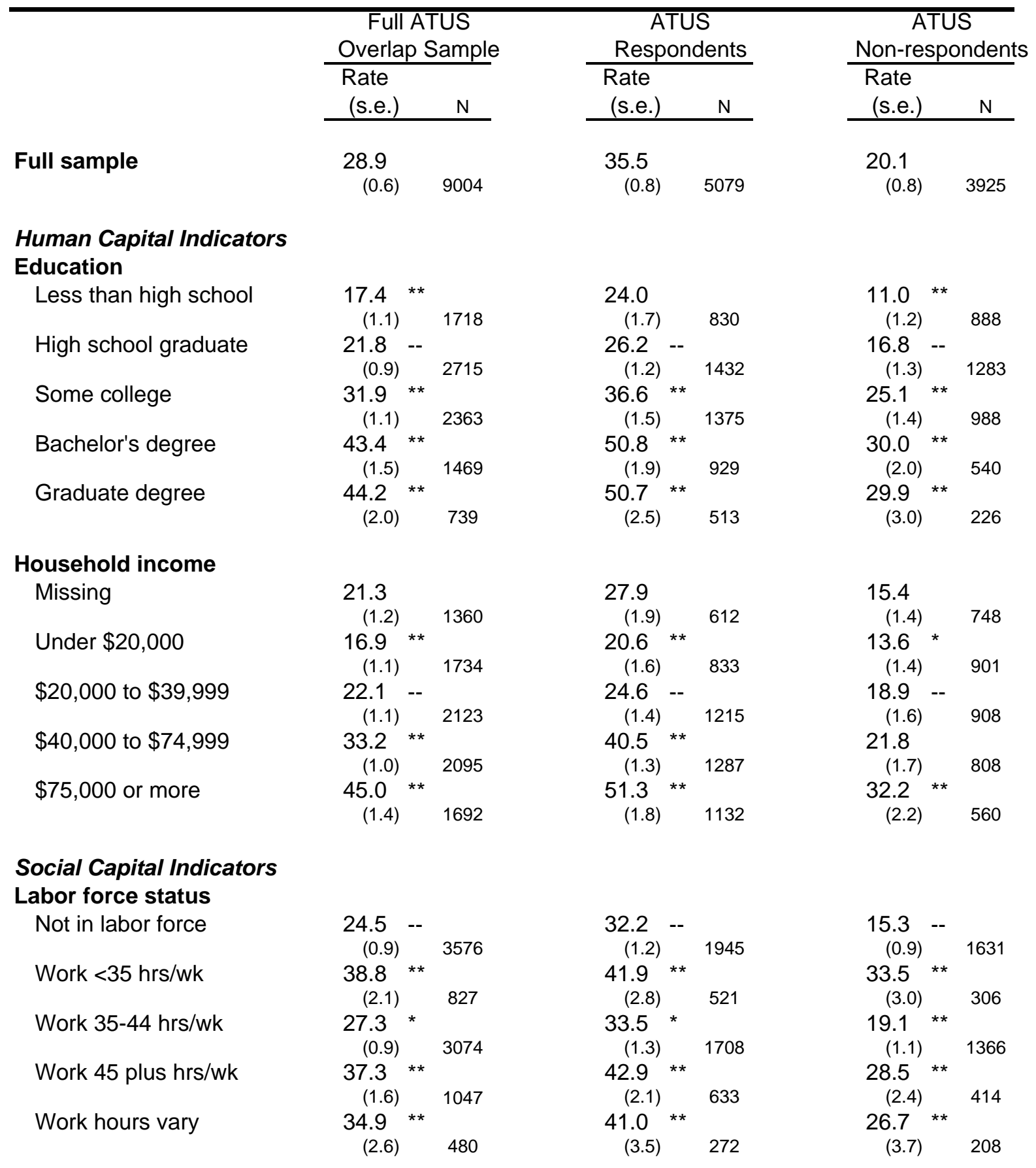


TABLE 2A: Volunteer rates calculated from the 2003 CPS volunteer supplement, full ATUS overlap sample, ATUS respondents and ATUS non-respondents, by selected background characteristics (continued)

\begin{tabular}{|c|c|c|c|c|c|c|}
\hline \multirow[b]{3}{*}{ Marital status } & \multicolumn{2}{|c|}{$\begin{array}{c}\text { Full ATUS } \\
\text { Overlap Sample }\end{array}$} & \multicolumn{2}{|c|}{$\begin{array}{c}\text { ATUS } \\
\text { Respondents } \\
\end{array}$} & \multicolumn{2}{|c|}{$\begin{array}{c}\text { ATUS } \\
\text { Non-respondents }\end{array}$} \\
\hline & $\begin{array}{l}\text { Rate } \\
\text { (s.e.) }\end{array}$ & $\mathrm{N}$ & $\begin{array}{l}\text { Rate } \\
\text { (s.e.) }\end{array}$ & $\mathrm{N}$ & $\begin{array}{l}\text { Rate } \\
\text { (s.e.) }\end{array}$ & $\mathrm{N}$ \\
\hline & & & & & & \\
\hline Married & $\begin{array}{c}34.4 \quad-- \\
(0.8)\end{array}$ & 4346 & $\begin{array}{c}40.4 \quad-- \\
(1.1)\end{array}$ & 2714 & $\begin{array}{c}24.2 \quad-- \\
(1.2)\end{array}$ & 1632 \\
\hline Widowed & $\begin{array}{c}22.3 \\
(1.6)\end{array}$ & 756 & $\begin{array}{c}31.2 \\
(2.6)\end{array}$ & 415 & $\underset{(1.8)}{11.9}$ & 341 \\
\hline Divorced & $\begin{array}{c}23.6 \\
(1.5)\end{array}$ & 1141 & $\begin{array}{c}29.0 \text { (2.2) }\end{array}$ & 628 & $\begin{array}{c}17.1 \\
(1.7)\end{array}$ & 513 \\
\hline Spouse absent & $\begin{array}{c}20.9 \\
(2.5)\end{array}$ & 432 & $\begin{array}{c}21.6 \\
(3.2)\end{array}$ & 214 & $\begin{array}{l}20.1 \\
(3.4)\end{array}$ & 218 \\
\hline Never married & $\begin{array}{c}22.9 \\
(1.1)\end{array}$ & 2329 & $\begin{array}{c}29.0 \\
(1.7)\end{array}$ & 1108 & $\begin{array}{l}17.1 \\
(1.2)\end{array}$ & 1221 \\
\hline Children in household & & & & & & \\
\hline No children under age 6 & $\begin{array}{c}28.6-- \\
(0.6)\end{array}$ & 7293 & $\begin{array}{c}35.1-- \\
(0.8)\end{array}$ & 4135 & $\begin{array}{l}19.7-- \\
(0.8)\end{array}$ & 3158 \\
\hline Children under age 6 & $\begin{array}{l}30.4 \\
(1.3)\end{array}$ & 1711 & $\begin{array}{l}37.3 \\
(1.9)\end{array}$ & 944 & $\begin{array}{l}21.8 \\
(1.7)\end{array}$ & 767 \\
\hline No children age 6-17 & $\begin{array}{c}25.1 \\
(0.7)\end{array}$ & 5928 & $\begin{array}{c}31.5 \\
(1.0)\end{array}$ & 3330 & $\begin{array}{c}16.7 \quad-- \\
(0.8)\end{array}$ & 2598 \\
\hline Children age 6-17 & $\begin{array}{c}36.4 \\
(1.1)\end{array}$ & 3076 & $\begin{array}{c}43.6 \quad \text { ** } \\
(1.5)\end{array}$ & 1749 & $\begin{array}{l}26.9 \\
(1.5)\end{array}$ & 1327 \\
\hline Others in household & & & & & & \\
\hline No relatives & $\begin{array}{c}30.5-- \\
(0.7)\end{array}$ & 7272 & $\begin{array}{c}36.9-- \\
(0.9)\end{array}$ & 4197 & $\begin{array}{c}21.1 \\
(0.8)\end{array}$ & 3075 \\
\hline One or more relatives & $\begin{array}{c}25.0 \\
(1.2)\end{array}$ & 1732 & $\begin{array}{c}31.5 \\
(1.8)\end{array}$ & 882 & $\begin{array}{c}17.8 * \\
(1.4)\end{array}$ & 850 \\
\hline No non-relatives & $\begin{array}{c}30.3-- \\
(0.6)\end{array}$ & 8286 & $\begin{array}{c}36.8-- \\
(0.9)\end{array}$ & 4763 & $\begin{array}{c}21.2 \quad-- \\
(0.8)\end{array}$ & 3523 \\
\hline One or more non-relatives & $\begin{array}{c}15.2 \\
(1.4)\end{array}$ & 718 & $\begin{array}{c}19.0 \\
(2.4)\end{array}$ & 316 & ${ }_{(1.6)}^{12.2}$ & 402 \\
\hline Housing tenure & & & & & & \\
\hline Missing & $\begin{array}{l}35.2 \\
(3.3)\end{array}$ & 258 & $\begin{array}{l}42.7 \\
(4.6)\end{array}$ & 142 & $\begin{array}{l}24.7 \\
(4.8)\end{array}$ & 116 \\
\hline Owner & $\begin{array}{c}31.5 \quad-- \\
(0.7)\end{array}$ & 6136 & $\begin{array}{c}38.2 \quad-- \\
(1.0)\end{array}$ & 3694 & $\begin{array}{c}21.4 \\
(0.9)\end{array}$ & 2442 \\
\hline Renter & $\begin{array}{c}20.6 \text { ** } \\
(1.0)\end{array}$ & 2610 & $\begin{array}{c}24.9 \\
(1.4)\end{array}$ & 1243 & $\begin{array}{c}16.5 \\
(1.2)\end{array}$ & 1367 \\
\hline
\end{tabular}


TABLE 2A: Volunteer rates calculated from the 2003 CPS volunteer supplement, full ATUS overlap sample, ATUS respondents and ATUS non-respondents, by selected background characteristics (continued)

\begin{tabular}{|c|c|c|c|c|c|c|}
\hline \multirow[b]{3}{*}{ Telephone status } & \multicolumn{2}{|c|}{$\begin{array}{c}\text { Full ATUS } \\
\text { Overlap Sample }\end{array}$} & \multicolumn{2}{|c|}{$\begin{array}{c}\text { ATUS } \\
\text { Respondents } \\
\end{array}$} & \multicolumn{2}{|c|}{$\begin{array}{c}\text { ATUS } \\
\text { Non-respondents }\end{array}$} \\
\hline & $\begin{array}{l}\text { Rate } \\
\text { (s.e.) }\end{array}$ & $\mathrm{N}$ & $\begin{array}{l}\text { Rate } \\
\text { (s.e.) } \\
\end{array}$ & $\mathrm{N}$ & $\begin{array}{l}\text { Rate } \\
\text { (s.e.) }\end{array}$ & $\mathrm{N}$ \\
\hline & & & & & & \\
\hline Telephone household & $\begin{array}{c}29.5-- \\
(0.6)\end{array}$ & 8594 & $\begin{array}{c}36.0-- \\
(0.8)\end{array}$ & 4933 & $\begin{array}{c}20.6-- \\
(0.8)\end{array}$ & 3661 \\
\hline Non-telephone household & $\begin{array}{c}12.6 \\
(1.9)\end{array}$ & 410 & $\begin{array}{c}15.5 \\
(3.1)\end{array}$ & 146 & $\frac{11.0}{(2.1)}$ & 264 \\
\hline \multicolumn{7}{|l|}{$\begin{array}{l}\text { Other Characteristics } \\
\text { Sex }\end{array}$} \\
\hline Male & $25.5 \quad * *$ & 4023 & $\begin{array}{l}31.9 \\
(1.3)\end{array}$ & 2202 & $\begin{array}{c}17.5 \quad \text { ** } \\
(0.9)\end{array}$ & 1821 \\
\hline Female & $\begin{array}{c}31.9-- \\
(0.7)\end{array}$ & 4981 & $\begin{array}{c}38.5-- \\
(0.9)\end{array}$ & 2877 & $\begin{array}{c}22.5-- \\
(1.1)\end{array}$ & 2104 \\
\hline \multicolumn{7}{|l|}{ Age } \\
\hline Age $15-30$ & $\begin{array}{l}25.3 \\
(1.1)\end{array}$ & 2096 & $\begin{array}{l}30.6 \text { ** } \\
(1.7)\end{array}$ & 1025 & $\begin{array}{l}20.0 \\
(1.4)\end{array}$ & 1071 \\
\hline Age $31-45$ & $\begin{array}{c}34.0-- \\
(1.0)\end{array}$ & 2830 & $\begin{array}{c}41.0-- \\
(1.4)\end{array}$ & 1591 & $\begin{array}{c}24.8-- \\
(1.4)\end{array}$ & 1239 \\
\hline Age $46-55$ & $\begin{array}{l}33.9 \\
(1.3)\end{array}$ & 1486 & $\begin{array}{l}39.0 \\
(1.9)\end{array}$ & 918 & $\begin{array}{l}25.1 \\
(2.2)\end{array}$ & 568 \\
\hline Age $56-65$ & $\begin{array}{c}27.7 \\
(1.3)\end{array}$ & 1080 & $\begin{array}{l}34.1 \text { ** } \\
(1.8)\end{array}$ & 708 & $\begin{array}{c}14.9 * * \\
(2.1)\end{array}$ & 372 \\
\hline Over age 65 & $\begin{array}{c}21.1 \\
(1.2)\end{array}$ & 1512 & $\begin{array}{l}29.4 \text { (1.7) } \\
\text { ** }\end{array}$ & 837 & $\frac{10.9}{(1.4)}$ & 675 \\
\hline \multicolumn{7}{|l|}{ Race/ethnicity } \\
\hline Hispanic & $\begin{array}{c}14.8 \text { (1.2) }\end{array}$ & 1115 & $\begin{array}{c}17.6 \text { ** } \\
(1.9)\end{array}$ & 548 & $\begin{array}{c}12.1 \\
(1.5)\end{array}$ & 567 \\
\hline Non-Hispanic black & $\begin{array}{c}20.5 \\
(1.3)\end{array}$ & 1267 & $\begin{array}{c}25.2 \\
(2.4)\end{array}$ & 561 & $\begin{array}{c}16.9 \\
(1.6)\end{array}$ & 706 \\
\hline Non-Hispanic non-black & $\begin{array}{c}32.1-- \\
(0.6)\end{array}$ & 6622 & $\begin{array}{c}38.7 \quad-- \\
(0.9)\end{array}$ & 3970 & $\begin{array}{c}22.2-- \\
(0.9)\end{array}$ & 2652 \\
\hline \multicolumn{7}{|l|}{ Urbanicity of residence } \\
\hline Central city & $\begin{array}{c}24.3 * * \\
(1.3)\end{array}$ & 2224 & $\begin{array}{l}31.0 \text { ** } \\
(1.8)\end{array}$ & 1131 & $\begin{array}{c}17.2 \\
(1.5)\end{array}$ & 1093 \\
\hline Balance of MSA & $\begin{array}{c}31.0-- \\
(0.8)\end{array}$ & 3774 & $\begin{array}{c}38.3-- \\
(1.2)\end{array}$ & 2154 & $\begin{array}{c}21.1-- \\
(1.1)\end{array}$ & 1620 \\
\hline Other metropolitan & $\begin{array}{c}28.1 \\
(1.5)\end{array}$ & 1278 & $\begin{array}{r}34.3 \\
(2.0)\end{array}$ & 739 & $\begin{array}{r}18.8 \\
(2.1)\end{array}$ & 539 \\
\hline Non-metropolitan & $\begin{array}{c}30.1 \\
(1.3)\end{array}$ & 1705 & $\begin{array}{c}34.7 \\
(1.7)\end{array}$ & 1039 & $\begin{array}{r}22.9 \\
(1.8)\end{array}$ & 666 \\
\hline Not identified & $\begin{array}{c}26.5 \\
(13.8)\end{array}$ & 23 & $\begin{array}{c}32.2 \\
(15.7)\end{array}$ & 16 & $\begin{array}{c}13.5 \\
(14.4)\end{array}$ & 7 \\
\hline
\end{tabular}


TABLE 2A: Volunteer rates calculated from the 2003 CPS volunteer supplement, full ATUS overlap sample, ATUS respondents and ATUS non-respondents, by selected background characteristics (continued)

\begin{tabular}{|c|c|c|c|c|c|c|}
\hline \multirow{2}{*}{ Region of residence } & $\begin{array}{c}\text { Full A7 } \\
\text { Overlap } \subseteq \\
\text { Rate } \\
\text { (s.e.) } \\
\end{array}$ & $\begin{array}{l}\text { US } \\
\text { ample } \\
\mathrm{N} \\
\end{array}$ & $\begin{array}{l}\text { ATU } \\
\text { Respon } \\
\text { Rate } \\
\text { (s.e.) } \\
\end{array}$ & $\begin{array}{l}\text { Sents } \\
\mathrm{N} \\
\end{array}$ & \multicolumn{2}{|c|}{$\begin{array}{c}\text { ATUS } \\
\text { Non-respondents }\end{array}$} \\
\hline & & & & & & \\
\hline Northeast & $\begin{array}{l}26.2 \\
(1.1)\end{array}$ & 1739 & $\begin{array}{l}32.7 \\
(1.6)\end{array}$ & 994 & $\begin{array}{l}17.6 \\
(1.5)\end{array}$ & 745 \\
\hline South & $\begin{array}{c}27.3-- \\
(0.9)\end{array}$ & 3316 & $\begin{array}{c}32.9-- \\
(1.3)\end{array}$ & 1754 & $\begin{array}{c}20.6 \\
(1.2)\end{array}$ & 1562 \\
\hline West & $\begin{array}{l}29.2 \\
(1.5) \\
33 .\end{array}$ & 1858 & $\begin{array}{l}36.4 \\
(1.9) \\
40.1\end{array}$ & 1064 & $\begin{array}{l}19.3 \\
(1.6) \\
22.0\end{array}$ & 794 \\
\hline Midwest & (1.1) & 2091 & (1.4) & 1267 & (1.7) & 824 \\
\hline
\end{tabular}

Note: All estimates are weighted using the ATUS sample weights. Standard errors reported in parentheses have been adjusted to account for the clustering and weighting of the sample.

** Significantly different from reference group mean at 0.01 level

* Significantly different from reference group mean at 0.05 level

-- Reference group 
TABLE 2B: Volunteer hours calculated from the 2003 CPS volunteer supplement, full ATUS overlap sample, ATUS respondents and ATUS non-respondents, by selected background characteristics

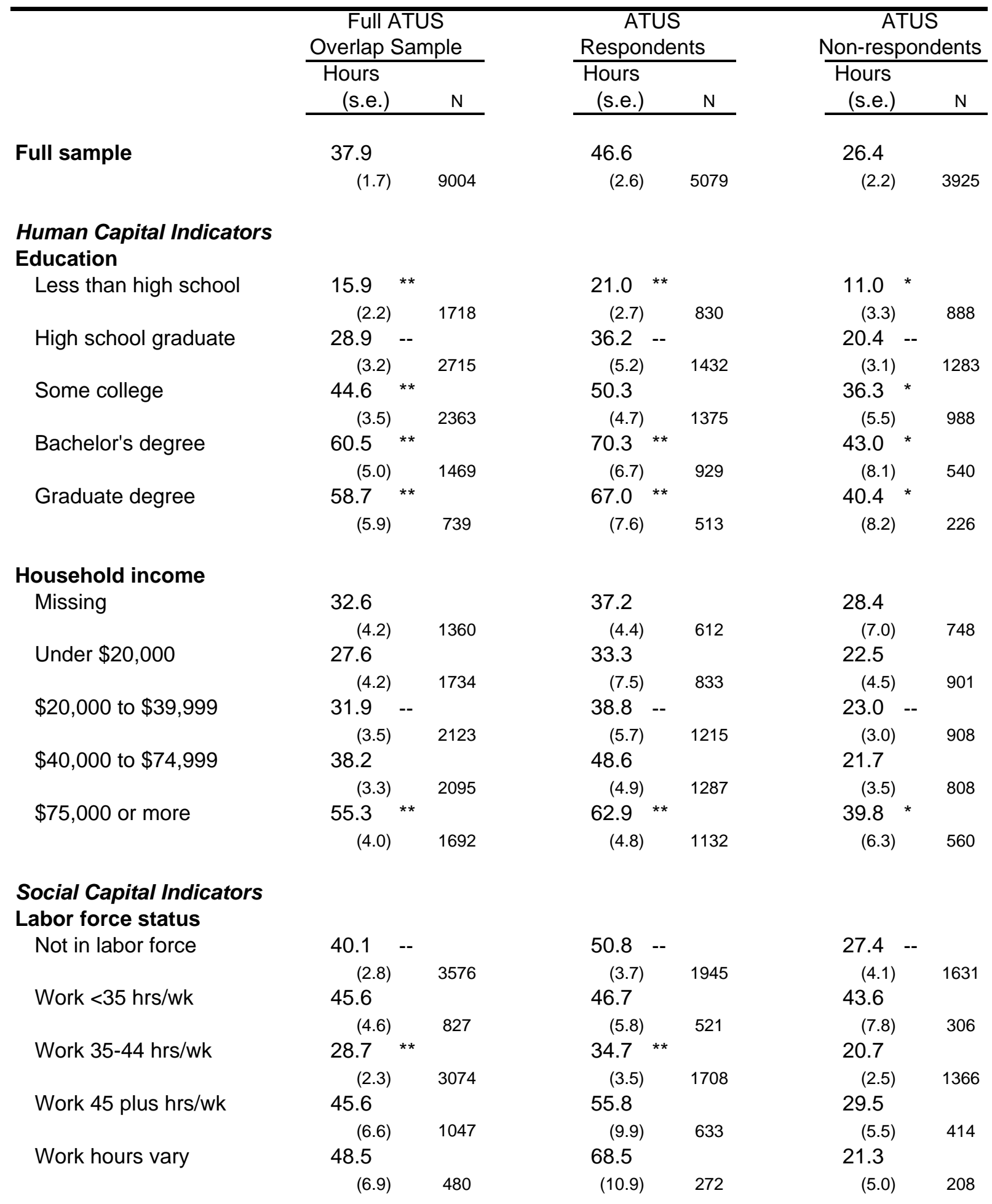


TABLE 2B: Volunteer hours calculated from the 2003 CPS volunteer supplement, full ATUS overlap sample, ATUS respondents and ATUS non-respondents, by selected background characteristics (continued)

\begin{tabular}{|c|c|c|c|c|c|c|}
\hline \multirow[b]{3}{*}{ Marital status } & \multicolumn{2}{|c|}{$\begin{array}{c}\text { Full ATUS } \\
\text { Overlap Sample } \\
\end{array}$} & \multicolumn{2}{|c|}{$\begin{array}{c}\text { ATUS } \\
\text { Respondents } \\
\end{array}$} & \multicolumn{2}{|c|}{$\begin{array}{c}\text { ATUS } \\
\text { Non-respondents }\end{array}$} \\
\hline & $\begin{array}{c}\text { Hours } \\
\text { (s.e.) } \\
\end{array}$ & $\mathrm{N}$ & $\begin{array}{l}\text { Hours } \\
\text { (s.e.) } \\
\end{array}$ & $\mathrm{N}$ & $\begin{array}{c}\text { Hours } \\
\text { (s.e.) } \\
\end{array}$ & $\mathrm{N}$ \\
\hline & & & & & & \\
\hline Married & $\begin{array}{l}44.8 \\
\quad(2.7)\end{array}$ & $\begin{array}{ll}-- & \\
& 4346\end{array}$ & $\begin{array}{c}53.5-- \\
(3.9)\end{array}$ & 2714 & $\begin{array}{c}30.0 \quad-- \\
(3.2)\end{array}$ & 1632 \\
\hline Widowed & $\begin{array}{l}47.7 \\
\quad(5.8)\end{array}$ & 756 & $\begin{array}{l}69.9 \\
(9.8)\end{array}$ & 415 & $\begin{array}{l}21.7 \\
(7.1)\end{array}$ & 341 \\
\hline Divorced & $\begin{array}{l}28.0 \\
\quad(3.4)\end{array}$ & ** 1141 & $\begin{array}{c}33.5 \\
(4.8)\end{array}$ & 628 & $\begin{array}{l}21.2 \\
(4.7)\end{array}$ & 513 \\
\hline Spouse absent & $\begin{array}{l}26.6 \\
(5.4)\end{array}$ & ** & $\begin{array}{c}26.4 \\
(8.6)\end{array}$ & 214 & $\begin{array}{l}26.8 \\
(6.8)\end{array}$ & 218 \\
\hline Never married & $\begin{array}{l}27.4 \\
\quad(3.1)\end{array}$ & ** 2329 & $\begin{array}{c}30.9 * * \\
(4.5)\end{array}$ & 1108 & $\begin{array}{l}24.1 \\
\quad(4.3)\end{array}$ & 1221 \\
\hline Children in household & & & & & & \\
\hline No children under age 6 & $\begin{array}{l}39.1 \\
\quad(2.0)\end{array}$ & $\begin{array}{l}-- \\
-7293\end{array}$ & $\begin{array}{c}47.9-- \\
(2.9)\end{array}$ & 4135 & $\begin{array}{c}27.3 \quad-- \\
(2.5)\end{array}$ & 3158 \\
\hline Children under age 6 & $\begin{array}{r}31.8 \\
(2.9)\end{array}$ & 1711 & $\begin{array}{l}39.6 \\
(4.3)\end{array}$ & 944 & $\begin{array}{l}22.0 \\
(3.7)\end{array}$ & 767 \\
\hline No children age 6-17 & $\begin{array}{r}35.7 \\
(2.0)\end{array}$ & 5928 & $\begin{array}{c}44.2-- \\
(2.9)\end{array}$ & 3330 & $\begin{array}{c}24.3-- \\
(2.7)\end{array}$ & 2598 \\
\hline Children age 6-17 & $\begin{array}{l}42.4 \\
\quad(2.8)\end{array}$ & 3076 & $\begin{array}{l}51.3 \\
(4.5)\end{array}$ & 1749 & $\begin{array}{l}30.6 \\
(3.7)\end{array}$ & 1327 \\
\hline Others in household & & & & & & \\
\hline No relatives & $\begin{array}{l}39.9 \\
(2.0)\end{array}$ & 7272 & $\begin{array}{c}48.0-- \\
(2.9)\end{array}$ & 4197 & $\begin{array}{c}28.1 \quad-- \\
(2.6)\end{array}$ & 3075 \\
\hline One or more relatives & $\begin{array}{l}33.1 \\
\quad(3.3)\end{array}$ & 1732 & $\begin{array}{l}42.6 \\
(4.8)\end{array}$ & 882 & $\begin{array}{l}22.8 \\
\quad(4.2)\end{array}$ & 850 \\
\hline No non-relatives & $\begin{array}{l}39.4 \\
(1.7)\end{array}$ & $\begin{array}{ll}-- & \\
& 8286\end{array}$ & $\begin{array}{c}47.6-- \\
(2.6)\end{array}$ & 4763 & $\begin{array}{c}28.0-- \\
(2.4)\end{array}$ & 3523 \\
\hline One or more non-relatives & $\begin{array}{l}23.5 \\
\quad(5.8)\end{array}$ & 718 & $\begin{array}{l}34.0 \\
(11.7)\end{array}$ & 316 & $\begin{array}{l}15.0 \\
(4.4)\end{array}$ & 402 \\
\hline Housing tenure & & & & & & \\
\hline Missing & $\begin{array}{l}49.2 \\
(12.0)\end{array}$ & 258 & $\begin{array}{l}49.4 \\
(13.3)\end{array}$ & 142 & $\begin{array}{l}48.9 \\
(23.5)\end{array}$ & 116 \\
\hline Owner & $\begin{array}{l}40.5 \\
(2.2)\end{array}$ & $\begin{array}{ll}-- & \\
& 6136\end{array}$ & $\begin{array}{c}49.9-- \\
(3.3)\end{array}$ & 3694 & $\begin{array}{c}26.2 \quad-- \\
(2.5)\end{array}$ & 2442 \\
\hline Renter & $\begin{array}{l}29.2 \\
\quad(2.9)\end{array}$ & ** 2610 & $\begin{array}{c}34.6 \text { ** } \\
(4.7)\end{array}$ & 1243 & $\begin{array}{l}24.1 \\
(3.7)\end{array}$ & 1367 \\
\hline
\end{tabular}


TABLE 2B: Volunteer hours calculated from the 2003 CPS volunteer supplement, full ATUS overlap sample, ATUS respondents and ATUS non-respondents, by selected background characteristics (continued)

\begin{tabular}{|c|c|c|c|c|c|c|}
\hline \multirow[b]{3}{*}{ Telephone status } & \multicolumn{2}{|c|}{$\begin{array}{c}\text { Full ATUS } \\
\text { Overlap Sample } \\
\end{array}$} & \multicolumn{2}{|c|}{$\begin{array}{c}\text { ATUS } \\
\text { Respondents } \\
\end{array}$} & \multicolumn{2}{|c|}{$\begin{array}{c}\text { ATUS } \\
\text { Non-respondents } \\
\text { Hours }\end{array}$} \\
\hline & $\begin{array}{l}\text { Hours } \\
\text { (s.e.) } \\
\end{array}$ & $\mathrm{N}$ & $\begin{array}{l}\text { Hours } \\
\text { (s.e.) } \\
\end{array}$ & $\mathrm{N}$ & & $\mathrm{N}$ \\
\hline & & & & & & \\
\hline Telephone household & $\begin{array}{l}39.0 \\
\quad(1.8)\end{array}$ & $\begin{array}{ll}-- & \\
& 8594\end{array}$ & $\begin{array}{c}47.4-- \\
(2.7)\end{array}$ & 4933 & $\begin{array}{c}27.4-- \\
(2.3)\end{array}$ & 3661 \\
\hline Non-telephone household & $\begin{array}{l}10.3 \\
(2.6)\end{array}$ & ** 410 & $\begin{array}{l}12.8 \text { ** } \\
(4.2)\end{array}$ & 146 & $\begin{array}{l}8.8 \text { ** } \\
(3.7)\end{array}$ & 264 \\
\hline $\begin{array}{l}\text { Other Characteristics } \\
\text { Sex }\end{array}$ & & & & & & \\
\hline Male & $\begin{array}{r}33.0 \\
\quad(2.5)\end{array}$ & ** 4023 & $\begin{array}{l}40.6 * \\
(3.5)\end{array}$ & 2202 & $\begin{array}{c}23.6-- \\
(3.3)\end{array}$ & 1821 \\
\hline Female & $\begin{array}{l}42.3 \\
\quad(2.5)\end{array}$ & $\begin{array}{ll}-- & \\
- & 4981\end{array}$ & $\begin{array}{c}51.6-- \\
(3.7)\end{array}$ & 2877 & $\begin{array}{l}29.0 \\
(2.9)\end{array}$ & 2104 \\
\hline Age & & & & & & \\
\hline Age $15-30$ & $\begin{array}{l}27.9 \\
(3.3)\end{array}$ & * 2096 & $\begin{array}{l}31.3 \\
(4.9)\end{array}$ & 1025 & $\begin{array}{l}24.6 \\
(4.6)\end{array}$ & 1071 \\
\hline Age $31-45$ & $\begin{array}{l}37.5 \\
(3.1)\end{array}$ & $\begin{array}{ll}-- & \\
& 2830\end{array}$ & $\begin{array}{c}44.4-- \\
(4.4)\end{array}$ & 1591 & $\begin{array}{c}28.4 \quad-- \\
(3.5)\end{array}$ & 1239 \\
\hline Age $46-55$ & $\begin{array}{l}45.8 \\
(4.3)\end{array}$ & 1486 & $\begin{array}{l}54.2 \\
(6.3)\end{array}$ & 918 & $\begin{array}{l}31.5 \\
(5.3)\end{array}$ & 568 \\
\hline Age $56-65$ & $\begin{array}{l}40.7 \\
(4.6)\end{array}$ & 1080 & $\begin{array}{l}47.2 \\
(6.3)\end{array}$ & 708 & $\begin{array}{l}27.7 \\
(6.7)\end{array}$ & 372 \\
\hline Over age 65 & $\begin{array}{l}43.3 \\
\quad(4.4)\end{array}$ & 1512 & $\begin{array}{c}61.3 * \\
(6.1)\end{array}$ & 837 & $\begin{array}{l}20.9 \\
(5.5)\end{array}$ & 675 \\
\hline Race/ethnicity & & & & & & \\
\hline Hispanic & $\begin{array}{l}18.0 \\
(3.2)\end{array}$ & ** 1115 & $\begin{array}{c}14.7 \text { ** } \\
(2.6)\end{array}$ & 548 & $\begin{array}{l}21.3 \\
(5.7)\end{array}$ & 567 \\
\hline Non-Hispanic black & $\begin{array}{l}27.6 \\
(4.2)\end{array}$ & 1267 & $\begin{array}{c}31.6 \text { ** } \\
(5.4)\end{array}$ & 561 & $\begin{array}{l}24.5 \\
(6.4)\end{array}$ & 706 \\
\hline Non-Hispanic non-black & $\begin{array}{l}42.3 \\
\quad(2.1)\end{array}$ & $\begin{array}{l}-- \\
\quad 6622\end{array}$ & $\begin{array}{c}52.0-- \\
(3.1)\end{array}$ & 3970 & $\begin{array}{c}27.7-- \\
(2.4)\end{array}$ & 2652 \\
\hline Urbanicity of residence & & & & & & \\
\hline Central city & $\begin{array}{r}34.1 \\
(3.6)\end{array}$ & 2224 & $\begin{array}{l}46.4 \\
(6.3)\end{array}$ & 1131 & $\begin{array}{l}21.3 \\
(3.0)\end{array}$ & 1093 \\
\hline Balance of MSA & $\begin{array}{l}38.3 \\
\quad(2.4)\end{array}$ & $\begin{array}{ll}-- & \\
& 3774\end{array}$ & $\begin{array}{c}46.2-- \\
(3.0)\end{array}$ & 2154 & $\begin{array}{c}27.5-- \\
(3.7)\end{array}$ & 1620 \\
\hline Other metropolitan & $\begin{aligned} 33.1 \\
\quad(3.3)\end{aligned}$ & 1278 & $\begin{array}{l}39.9 \\
(4.8)\end{array}$ & 739 & $\begin{array}{l}22.9 \\
(4.0)\end{array}$ & 539 \\
\hline Non-metropolitan & $\begin{array}{l}45.7 \\
\quad(4.8)\end{array}$ & 1705 & $\begin{array}{l}52.8 \\
(7.4)\end{array}$ & 1039 & $\begin{array}{r}34.5 \\
(6.2)\end{array}$ & 666 \\
\hline Not identified & $\begin{array}{l}15.9 \\
(8.5)\end{array}$ & * & $\begin{array}{c}21.2 \\
(11.2)\end{array}$ & 16 & $\begin{array}{c}4.1 \\
(4.3)\end{array}$ & 7 \\
\hline
\end{tabular}


TABLE 2B: Volunteer hours calculated from the 2003 CPS volunteer supplement, full ATUS overlap sample, ATUS respondents and ATUS non-respondents, by selected background characteristics (continued)

\begin{tabular}{|c|c|c|c|c|c|c|}
\hline \multirow{3}{*}{$\begin{array}{l} \\
\text { Region of residence } \\
\text { Northeast }\end{array}$} & \multicolumn{2}{|c|}{$\begin{array}{c}\text { Full ATUS } \\
\text { Overlap Sample } \\
\text { Hours }\end{array}$} & \multicolumn{2}{|c|}{$\begin{array}{c}\text { ATUS } \\
\text { Respondents }\end{array}$} & \multicolumn{2}{|c|}{$\begin{array}{c}\text { ATUS } \\
\text { Non-respondents }\end{array}$} \\
\hline & $\begin{array}{c}\text { Hours } \\
\text { (s.e.) } \\
\end{array}$ & $\mathrm{N}$ & $\begin{array}{l}\text { Hours } \\
\text { (s.e.) }\end{array}$ & $\mathrm{N}$ & $\begin{array}{r}\text { Hours } \\
\text { (s.e.) } \\
\end{array}$ & $\mathrm{N}$ \\
\hline & & & & & & \\
\hline Northeast & $\begin{array}{l}36.0 \\
\quad(3.8)\end{array}$ & 1739 & $\begin{array}{l}45.6 \\
(5.0)\end{array}$ & 994 & $\begin{array}{l}23.3 \\
(5.9)\end{array}$ & 745 \\
\hline South & $\begin{array}{c}35.1 \\
(2.5)\end{array}$ & 3316 & $\begin{array}{c}41.1-- \\
(3.8)\end{array}$ & 1754 & $\begin{array}{c}28.1-- \\
(3.5)\end{array}$ & 1562 \\
\hline West & $\begin{array}{l}43.2 \\
(3.9)\end{array}$ & 1858 & $\begin{array}{c}55.9 \\
(6.1)\end{array}$ & 1064 & $\begin{array}{c}25.9 \\
(3.9)\end{array}$ & 794 \\
\hline Midwest & $\begin{array}{r}38.6 \\
(3.0)\end{array}$ & 2091 & $\begin{array}{l}46.0 \\
(4.7)\end{array}$ & 1267 & $\begin{array}{l}26.6 \\
(4.0)\end{array}$ & 824 \\
\hline
\end{tabular}

Note: All estimates are weighted using the ATUS sample weights. Standard errors reported in parentheses have been adjusted to account for the clustering and weighting of the sample.

** Significantly different from reference group mean at 0.01 level

* Significantly different from reference group mean at 0.05 level

-- Reference group 
Table 3: Two-part models of volunteer activity, September 2003 CPS Volunteer supplement, full ATUS overlap sample and ATUS respondents

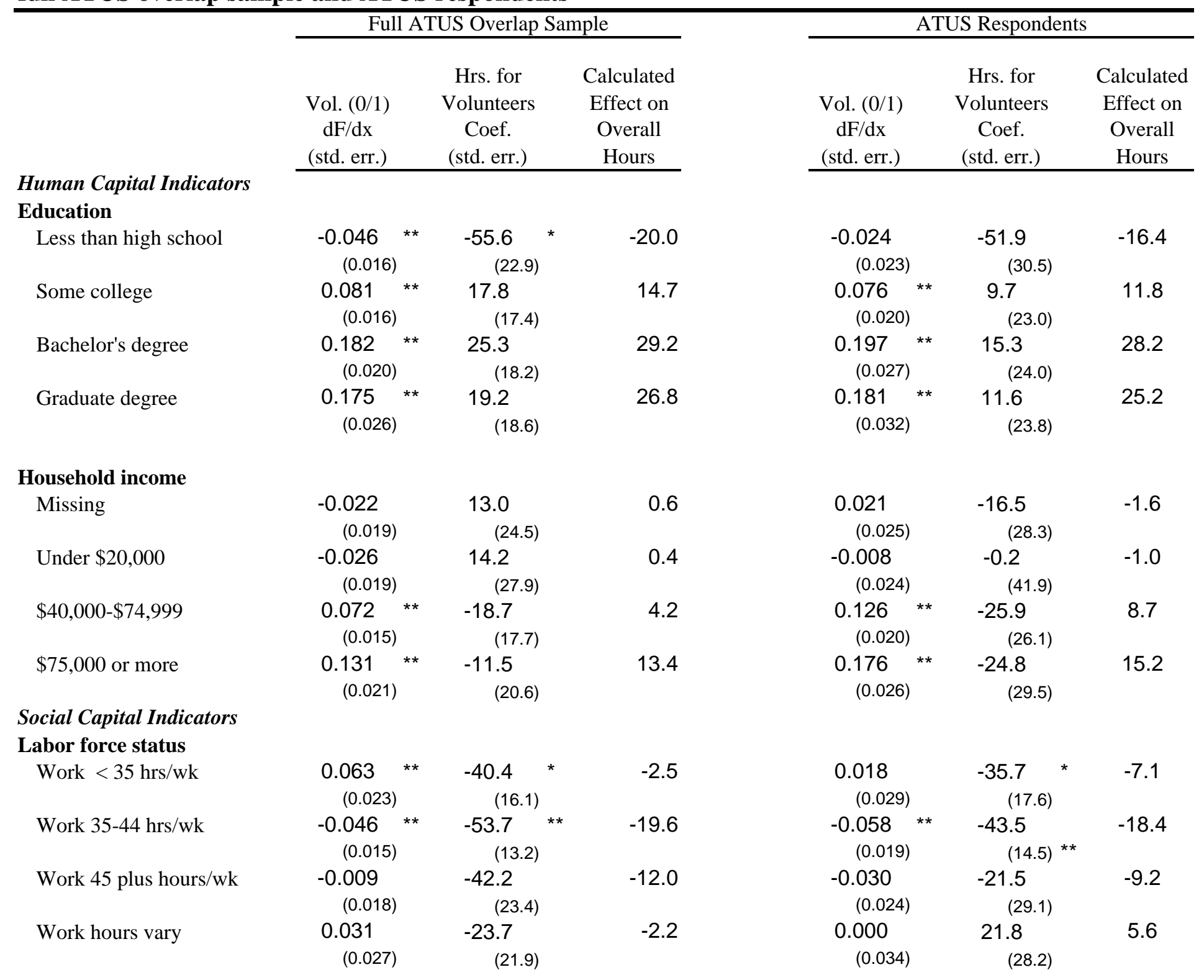


Table 3: Two-part models of volunteer activity, September 2003 CPS Volunteer supplement, full ATUS overlap sample and ATUS respondent sample (continued)

\begin{tabular}{|c|c|c|c|c|c|c|c|}
\hline & \multicolumn{3}{|c|}{ Full ATUS Overlap Sample } & \multicolumn{4}{|c|}{ ATUS Respondents } \\
\hline & $\begin{array}{c}\text { Vol. }(0 / 1) \\
\text { dF/dx } \\
\text { (std. err.) } \\
\end{array}$ & $\begin{array}{c}\text { Hrs. for } \\
\text { Volunteers } \\
\text { Coef. } \\
\text { (std. err.) } \\
\end{array}$ & $\begin{array}{c}\text { Calculated } \\
\text { Effect on } \\
\text { Overall } \\
\text { Hours } \\
\end{array}$ & $\begin{array}{c}\text { Vol. (0/1) } \\
\text { dF/dx } \\
\text { (std. err.) }\end{array}$ & & $\begin{array}{c}\text { Hrs. for } \\
\text { Volunteers } \\
\text { Coef. } \\
\text { (std. err.) } \\
\end{array}$ & $\begin{array}{c}\text { Calculated } \\
\text { Effect on } \\
\text { Overall } \\
\text { Hours } \\
\end{array}$ \\
\hline \multicolumn{8}{|l|}{ Marital status } \\
\hline Widowed & $\begin{array}{l}0.026 \\
\quad(0.027)\end{array}$ & $\begin{array}{l}34.7 \\
(27.8)\end{array}$ & 12.2 & $\begin{array}{l}0.040 \\
\quad(0.035)\end{array}$ & & $\begin{array}{l}39.7 \\
(34.5)\end{array}$ & 15.2 \\
\hline Divorced & $\begin{array}{r}-0.022 \\
(0.018)\end{array}$ & $\begin{array}{r}-20.2 \\
(20.2)\end{array}$ & -7.9 & $\begin{array}{r}-0.011 \\
(0.023)\end{array}$ & & $\begin{array}{r}-35.4 \\
(26.4)\end{array}$ & -10.5 \\
\hline Spouse absent & $\begin{array}{r}-0.014 \\
(0.030)\end{array}$ & $\begin{array}{l}-8.0 \\
(24.0)\end{array}$ & -3.8 & $\begin{array}{r}-0.035 \\
(0.037)\end{array}$ & & $\begin{array}{l}-18.0 \\
(36.2)\end{array}$ & -8.9 \\
\hline Never married & $\begin{array}{r}-0.030 \\
(0.018)\end{array}$ & $\begin{array}{l}7.2 \\
(14.9)\end{array}$ & -1.9 & $\begin{array}{r}-0.015 \\
(0.023)\end{array}$ & & $\begin{array}{r}-12.6 \\
(18.5)\end{array}$ & -5.1 \\
\hline \multicolumn{8}{|l|}{ Children in household } \\
\hline Children under age 6 & $\begin{array}{r}-0.019 \\
(0.014)\end{array}$ & $\begin{array}{r}-14.2 \\
(11.3)\end{array}$ & -6.1 & $\begin{array}{r}-0.015 \\
\quad(0.019)\end{array}$ & & $\begin{array}{r}-11.7 \\
(13.1)\end{array}$ & -4.9 \\
\hline Children age 6-17 & $\begin{array}{c}0.125 \text { ** } \\
(0.015)\end{array}$ & $\begin{array}{l}11.0 \\
(11.5)\end{array}$ & 18.4 & $\begin{array}{l}0.133 \\
\quad(0.021)\end{array}$ & ** & $\begin{array}{l}20.7 \\
\quad(15.1)\end{array}$ & 21.6 \\
\hline \multicolumn{8}{|l|}{ Others in household } \\
\hline One or more relatives & $\begin{array}{c}-0.055 * * \\
(0.013)\end{array}$ & $\begin{array}{l}13.1 \\
(14.0)\end{array}$ & -3.6 & $\begin{array}{r}-0.049 \\
\quad(0.017)\end{array}$ & ** & $\begin{array}{l}20.6 \\
(17.4)\end{array}$ & -0.6 \\
\hline One or more nonrelatives & $\begin{array}{c}-0.104 \text { ** } \\
(0.019)\end{array}$ & $\begin{array}{l}28.4 \\
\quad(36.8)\end{array}$ & -5.7 & $\begin{array}{r}-0.109 \\
\quad(0.026)\end{array}$ & ** & $\begin{array}{l}66.6 \\
\quad(56.8)\end{array}$ & 3.9 \\
\hline \multicolumn{8}{|l|}{ Housing tenure } \\
\hline Missing & $\begin{array}{l}0.039 \\
\quad(0.034)\end{array}$ & $\begin{array}{l}14.5 \\
(31.2)\end{array}$ & 8.6 & $\begin{array}{l}0.044 \\
\quad(0.048)\end{array}$ & & $\begin{array}{r}-15.2 \\
(27.2)\end{array}$ & 1.4 \\
\hline Renter & $\begin{array}{c}-0.034 \text { ** } \\
(0.013)\end{array}$ & $\begin{array}{l}13.4 \\
(13.4)\end{array}$ & -0.8 & $\begin{array}{r}-0.038 \\
(0.018)\end{array}$ & * & $\begin{array}{l}8.8 \\
(15.9)\end{array}$ & -2.3 \\
\hline \multicolumn{8}{|l|}{ Telephone status } \\
\hline Non-telephone household & $\begin{array}{c}-0.078 \text { ** } \\
(0.026)\end{array}$ & $\begin{array}{c}-53.0 \text { * } \\
(26.1)\end{array}$ & -23.3 & $\begin{array}{r}-0.089 \\
(0.039)\end{array}$ & * & $\begin{array}{r}-37.7 \\
(31.1)\end{array}$ & -20.7 \\
\hline
\end{tabular}


Table 3: Two-part models of volunteer activity, September 2003 CPS Volunteer supplement, full ATUS overlap sample and ATUS respondent sample (continued)

\begin{tabular}{|c|c|c|c|c|c|c|}
\hline & \multicolumn{3}{|c|}{ Full ATUS Overlap Sample } & \multicolumn{3}{|c|}{ ATUS Respondents } \\
\hline & $\begin{array}{c}\text { Vol. (0/1) } \\
\text { dF/dx } \\
\text { (std. err.) }\end{array}$ & $\begin{array}{c}\text { Hrs. for } \\
\text { Volunteers } \\
\text { Coef. } \\
\text { (std. err.) } \\
\end{array}$ & $\begin{array}{c}\text { Calculated } \\
\text { Effect on } \\
\text { Overall } \\
\text { Hours } \\
\end{array}$ & $\begin{array}{c}\text { Vol. (0/1) } \\
\text { dF/dx } \\
\text { (std. err.) }\end{array}$ & $\begin{array}{c}\text { Hrs. for } \\
\text { Volunteers } \\
\text { Coef. } \\
\text { (std. err.) } \\
\end{array}$ & $\begin{array}{c}\text { Calculated } \\
\text { Effect on } \\
\text { Overall } \\
\text { Hours } \\
\end{array}$ \\
\hline \multicolumn{7}{|l|}{ Other Characteristics } \\
\hline \multicolumn{7}{|l|}{ Sex } \\
\hline Male & $\begin{array}{l}-0.060 * * \\
(0.011)\end{array}$ & $\begin{array}{c}4.4 \\
(11.7)\end{array}$ & -6.4 & $\begin{array}{l}-0.061 \text { ** } \\
(0.013)\end{array}$ & $\begin{array}{l}-3.9 \\
\quad(14.1)\end{array}$ & -8.5 \\
\hline \multicolumn{7}{|l|}{ Age } \\
\hline Under age 30 & $\begin{array}{l}0.014 \\
\quad(0.017)\end{array}$ & $\begin{array}{l}-0.5 \\
\quad(16.7)\end{array}$ & 1.7 & $\begin{array}{r}-0.007 \\
(0.020)\end{array}$ & $\begin{array}{l}10.2 \\
(21.0)\end{array}$ & 1.8 \\
\hline Age 46-55 & $\begin{array}{l}0.018 \\
\quad(0.018)\end{array}$ & $\begin{array}{l}26.4 \\
(15.8)\end{array}$ & 9.0 & $\begin{array}{l}0.002 \\
(0.020)\end{array}$ & $\begin{array}{l}32.5 \\
(19.0)\end{array}$ & 8.6 \\
\hline Age 56-65 & $\begin{array}{r}-0.019 \\
(0.020)\end{array}$ & $\begin{array}{l}31.0 \\
\quad(20.1)\end{array}$ & 5.5 & $\begin{array}{r}-0.011 \\
(0.024)\end{array}$ & $\begin{array}{l}30.4 \\
\quad(21.1)\end{array}$ & 6.5 \\
\hline Over age 65 & $\begin{array}{c}-0.056 \text { ** } \\
(0.024)\end{array}$ & $\begin{array}{c}57.2 \\
(24.7)\end{array}$ * & 7.6 & $\begin{array}{r}-0.034 \\
\quad(0.031)\end{array}$ & $\begin{array}{c}72.1 \text { ** } \\
(25.4)\end{array}$ & 14.5 \\
\hline \multicolumn{7}{|l|}{ Race/ethnicity } \\
\hline Hispanic & $\begin{array}{c}-0.097 \text { ** } \\
(0.018)\end{array}$ & $\begin{array}{l}-6.6 \\
(22.8)\end{array}$ & -13.8 & $\begin{array}{c}-0.113 \text { ** } \\
(0.023)\end{array}$ & $\begin{array}{c}-47.7 \text { * } \\
(19.8)\end{array}$ & -26.2 \\
\hline Non-Hispanic black & $\begin{array}{c}-0.048 \text { ** } \\
(0.016)\end{array}$ & $\begin{array}{l}2.8 \\
(21.9)\end{array}$ & -5.3 & $\begin{array}{c}-0.054 \text { * } \\
(0.029)\end{array}$ & $\begin{array}{l}-4.0 \\
\quad(25.8)\end{array}$ & -7.6 \\
\hline \multicolumn{7}{|l|}{ Urbanicity of residence } \\
\hline Central city & $\begin{array}{r}-0.013 \\
\quad(0.015)\end{array}$ & $\begin{array}{l}12.2 \\
(15.2)\end{array}$ & 1.4 & $\begin{array}{r}-0.006 \\
(0.020)\end{array}$ & $\begin{array}{l}28.7 \\
(19.2)\end{array}$ & 6.8 \\
\hline Other metropolitan & $\begin{array}{l}0.002 \\
\quad(0.018)\end{array}$ & $\begin{array}{l}-2.1 \\
(12.6)\end{array}$ & -0.3 & $\begin{array}{l}0.000 \\
\quad(0.022)\end{array}$ & $\begin{array}{l}4.3 \\
\quad(15.8)\end{array}$ & 1.1 \\
\hline Non-metropolitan & $\begin{array}{c}0.038 \text { * } \\
(0.016)\end{array}$ & $\begin{array}{l}30.0 \\
(17.9)\end{array}$ & 12.4 & $\begin{array}{l}0.029 \\
\quad(0.018)\end{array}$ & $\begin{array}{l}27.4 \\
\quad(22.8)\end{array}$ & 10.6 \\
\hline Not identified & $\begin{array}{r}-0.006 \\
\quad(0.146)\end{array}$ & $\begin{array}{c}-66.5 \\
(27.9)\end{array}$ * & -17.7 & $\begin{array}{l}0.005 \\
\quad(0.155)\end{array}$ & $\begin{array}{r}-52.8 \\
(41.5)\end{array}$ & -13.1 \\
\hline
\end{tabular}


Table 3: Two-part models of volunteer activity, September 2003 CPS Volunteer supplement, full ATUS overlap sample and ATUS respondent sample (continued)

\begin{tabular}{|c|c|c|c|c|c|c|}
\hline & \multicolumn{3}{|c|}{ Full ATUS Overlap Sample } & \multicolumn{3}{|c|}{ ATUS Respondents } \\
\hline & $\begin{array}{c}\text { Vol. }(0 / 1) \\
\text { dF/dx } \\
\text { (std. err.) }\end{array}$ & $\begin{array}{c}\text { Hrs. for } \\
\text { Volunteers } \\
\text { Coef. } \\
\text { (std. err.) }\end{array}$ & $\begin{array}{c}\text { Calculated } \\
\text { Effect on } \\
\text { Overall } \\
\text { Hours } \\
\end{array}$ & $\begin{array}{c}\text { Vol. }(0 / 1) \\
\text { dF/dx } \\
\text { (std. err.) }\end{array}$ & $\begin{array}{c}\text { Hrs. for } \\
\text { Volunteers } \\
\text { Coef. } \\
\text { (std. err.) }\end{array}$ & $\begin{array}{c}\text { Calculated } \\
\text { Effect on } \\
\text { Overall } \\
\text { Hours } \\
\end{array}$ \\
\hline \multicolumn{7}{|c|}{ Region of residence } \\
\hline Northeast & $\begin{array}{r}-0.027 \\
(0.014)\end{array}$ & $\begin{array}{l}4.0 \\
\quad(16.1)\end{array}$ & -2.4 & $\begin{array}{r}-0.017 \\
(0.019)\end{array}$ & $\begin{array}{l}16.4 \\
(18.1)\end{array}$ & 2.2 \\
\hline Midwest & $\begin{array}{l}0.026 \\
\quad(0.015)\end{array}$ & $\begin{array}{r}-17.2 \\
(11.4)\end{array}$ & -1.2 & $\begin{array}{c}0.040 \text { * } \\
\quad(0.019)\end{array}$ & $\begin{array}{r}-16.3 \\
(15.1)\end{array}$ & 0.6 \\
\hline West & $\begin{array}{r}-0.001 \\
\quad(0.016)\end{array}$ & $\begin{array}{l}16.5 \\
(15.0)\end{array}$ & 4.1 & $\begin{array}{l}0.023 \\
\quad(0.020)\end{array}$ & $\begin{array}{l}26.8 \\
(20.1)\end{array}$ & 9.8 \\
\hline Constant & & $\begin{array}{r}125.0 \\
(25.4)\end{array}$ & & & $\begin{array}{r}122.6 \\
(31.7)\end{array}$ & \\
\hline $\begin{array}{l}\mathbf{N} \\
\mathbf{R} 2\end{array}$ & 9004 & $\begin{array}{r}2609 \\
0.0356\end{array}$ & & 5079 & $\begin{array}{r}1804 \\
0.0430\end{array}$ & \\
\hline
\end{tabular}

Note: The volunteer propensity equation is a probit model. The numbers reported in the first and fourth columns are estimates of change in the volunteering rate implied by the probit coefficients. The volunteer hours equations in the second and fifth columns are least squares regressions estimated for those with positive volunteer hours. Estimated effects on overall hours appear in the third and sixth columns. All estimates are weighted using the ATUS sample weights. Standard errors reported in parentheses have been adjusted to account for the clustering and weighting of the sample.

** Statistically significant at the 0.01 level

* Statistically significant at the 0.05 level. 
TABLE 4: Volunteer hours calculated from the 2003 American Time Use Survey, by selected demographic characteristics

\begin{tabular}{|c|c|c|}
\hline & $\begin{array}{r}\text { Hours } \\
\text { (s.e.) } \\
\end{array}$ & $\mathrm{N}$ \\
\hline Full sample & $\begin{array}{l}53.5 \\
(2.2)\end{array}$ & 20720 \\
\hline \multicolumn{3}{|c|}{$\begin{array}{l}\text { Human Capital Indicators } \\
\text { Education }\end{array}$} \\
\hline Less than high school & $\begin{array}{l}34.8 \\
(5.3)\end{array}$ & 3634 \\
\hline High school graduate & $\begin{array}{c}37.6 \\
(3.5)\end{array}$ & 5790 \\
\hline Some college & $\begin{array}{c}58.4 \quad * * \\
(4.6)\end{array}$ & 5524 \\
\hline Bachelor's degree & $\begin{array}{c}74.7 \quad * * \\
(6.7)\end{array}$ & 3668 \\
\hline Graduate degree & $\begin{array}{c}82.0 \quad * * \\
(7.7)\end{array}$ & 2104 \\
\hline Household income & & \\
\hline Missing & $\begin{array}{r}40.2 \\
(5.0)\end{array}$ & 2451 \\
\hline Under $\$ 20,000$ & $\begin{array}{l}40.3 \\
(5.6)\end{array}$ & 3506 \\
\hline$\$ 20,000$ to $\$ 39,999$ & $\begin{array}{c}48.2-- \\
(4.4)\end{array}$ & 4726 \\
\hline$\$ 40,000$ to $\$ 74,999$ & $\begin{array}{l}57.2 \\
(4.7)\end{array}$ & 5330 \\
\hline$\$ 75,000$ or more & $\begin{array}{c}67.1 \\
(5.7)\end{array}$ & 4707 \\
\hline $\begin{array}{l}\text { Social Capital Indicato } \\
\text { Labor force status }\end{array}$ & & \\
\hline Not in labor force & $\begin{array}{c}66.2 \quad-- \\
(4.1)\end{array}$ & 7657 \\
\hline Work <35 hrs/wk & $\begin{array}{l}70.4 \\
(7.4)\end{array}$ & 2125 \\
\hline Work 35-44 hrs/wk & $\begin{array}{c}37.4 \quad * * \\
(2.9)\end{array}$ & 7098 \\
\hline Work 45 plus hrs/wk & $\begin{array}{c}46.7 \quad \star * \\
(6.1)\end{array}$ & 2754 \\
\hline Work hours vary & $\begin{array}{l}47.3 \\
\quad(11.5)\end{array}$ & 1086 \\
\hline Marital status & & \\
\hline Married & $\begin{array}{c}62.8 \quad-- \\
(3.1)\end{array}$ & 10825 \\
\hline Widowed & $\begin{array}{r}53.9 \\
(8.4)\end{array}$ & 1655 \\
\hline Divorced & $\begin{array}{c}35.7 \text { (5.3) }\end{array}$ & 2510 \\
\hline
\end{tabular}


TABLE 4: Volunteer hours calculated from the 2003 American Time Use Survey, by selected demographic characteristics (continued)

Marital status (continued)
Spouse absent
Never married
Children in household
No children under age 6
Children under age 6
No children age 6-17
Children age 6-17
Others in household
No relatives
One or more relatives
No nonrelatives
One or more non-relatives
Housing tenure
Owner
Renter
Telephone status
Nelephone household
Sex

Age

Age 15-30

Age 31-45

Age 46-55
Hours

\begin{tabular}{|c|c|c|}
\hline \multicolumn{2}{|l|}{ (s.e.) } & $\mathrm{N}$ \\
\hline \multicolumn{3}{|l|}{49.8} \\
\hline (17.8) & & 914 \\
\hline 39.1 & $\star *$ & \\
\hline$(4.2)$ & & 4816 \\
\hline 55.4 & -- & \\
\hline (2.5) & & 16778 \\
\hline 42.5 & * & \\
\hline (4.4) & & 3942 \\
\hline 46.7 & -- & \\
\hline$(2.7)$ & & 13217 \\
\hline
\end{tabular}

(4.0) 7503

$58.8--$

(2.6) $\quad 16945$

$39.4 * *$

3775

54.5 --

(2.2) $\quad 19366$

40.8

(9.9) $\quad 1354$

$59.1 \quad--$

(2.7) $\quad 15584$

31.8 **

(3.2) $\quad 5136$

$54.1 \quad--$

$\begin{array}{ll}(2.6) & 20168 \\ 22.6 & *\end{array}$

49.2

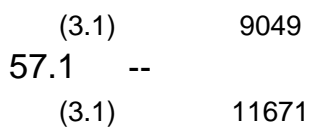

35.0 **

(4.4) 4327

52.7

(4.1) $\quad 6775$

60.5

(6.0) $\quad 3779$ 
TABLE 4: Volunteer hours calculated from the 2003 American Time Use Survey, by selected demographic characteristics (continued)

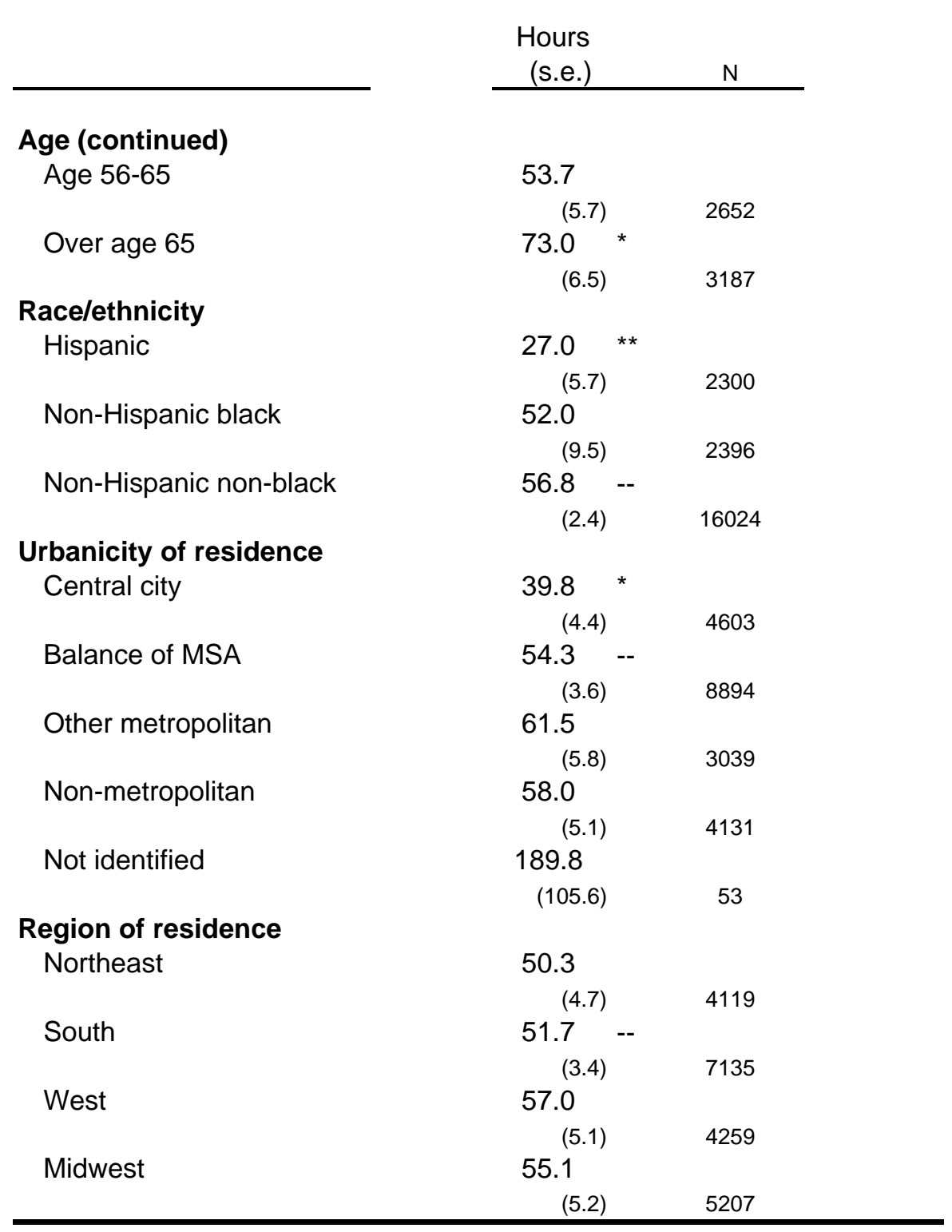

Note: All estimates are weighted using the ATUS sample weights, adjusted to account for the disproportionate assignment of cases to weekend days as compared to weekdays. Standard errors reported in parentheses have been adjusted to account for the clustering and weighting of the sample.

** Significantly different from reference group mean at 0.01 level

* Significantly different from reference group mean at 0.05 level

-- Reference group 